Portland State University

PDXScholar

Winter 3-20-2013

\title{
Expression of Growth Arrest and DNA Damage Protein 45-alpha (gadd45-alpha) and the CCAAT/ enhancer binding protein-delta (C/EBP-delta) in Fishes Exposed to Heat and Hypoxia
}

Daniel Omar Hassumani

Portland State University

Follow this and additional works at: https://pdxscholar.library.pdx.edu/open_access_etds

Part of the Cell Biology Commons

Let us know how access to this document benefits you.

\section{Recommended Citation}

Hassumani, Daniel Omar, "Expression of Growth Arrest and DNA Damage Protein 45-alpha (gadd45-alpha) and the CCAAT/enhancer binding protein-delta (C/EBP-delta) in Fishes Exposed to Heat and Hypoxia" (2013). Dissertations and Theses. Paper 943.

https://doi.org/10.15760/etd.943

This Thesis is brought to you for free and open access. It has been accepted for inclusion in Dissertations and Theses by an authorized administrator of PDXScholar. Please contact us if we can make this document more accessible: pdxscholar@pdx.edu. 
Expression of Growth Arrest and DNA Damage Protein 45-alpha (gadd45- $\alpha$ ) and the CCAAT/enhancer binding protein-delta (C/EBP- $\delta)$ in Fishes Exposed to Heat and Hypoxia

\author{
by
}

Daniel O. Hassumani

A thesis submitted in the partial fulfillment of the requirements for the degree of

\author{
Master of Science \\ in \\ Biology
}

Thesis committee:

Bradley A. Buckley, Chair

Jason E. Podrabsky

Sarah M. Eppley

Portland State University

2013 


\begin{abstract}
The cellular stress response (CSR) is one of the most highly conserved mechanisms among all organisms. Cellular stress can be defined as damage or the threat of damage to proteins, macromolecules and/or DNA. The response to damage can involve cell cycle regulation, protein chaperoning, DNA repair or, if macromolecular damage is too severe, apoptotic mechanisms can be initiated. This thesis details experiments that were designed to examine the cellular response to nonlethal environmental stressors at the protein level, using two fish species as study models. Two proteins that can cause cell cycle arrest and apoptosis mechanisms were examined. Expression of the CCAAT enhancer binding protein-delta $(\mathrm{C} / \mathrm{EBP}-\delta)$ was examined in the zebrafish, Danio rerio, exposed to acute, non-lethal hypoxic conditions. While $\mathrm{C} / \mathrm{EBP}-\delta$ was expressed constitutively in control individuals during all time points, exposure to hypoxic conditions did not have a consistent significant effect on $\mathrm{C} / \mathrm{EBP}-\delta$ expression (two-way ANOVA, $\mathrm{P}>0.05$ ) in zebrafish white muscle tissue. In a second study, the expression of the growth arrest and DNA damage 45- $\alpha$ protein (gadd45- $\alpha$ ), a mediator of cell cycle arrest and perhaps apoptosis was examined in heat-stressed liver tissue of an extremely cold-adapted Antarctic fish, Trematomus bernacchii. Gadd45- $\alpha$ levels were higher in fish exposure to $2^{\circ} \mathrm{C}$ across all time points (one-way ANOVA; $\mathrm{P}<0.05$ ). The findings in these two studies expand our understanding of the CSR and how two genes that are involved in cell cycle regulation respond to acute, non-lethal environmental stress.
\end{abstract}




\section{Dedication}

This thesis is dedicated to my entire family who has supported me and given me strength through some of the most incredible times of my life and some of the most difficult times as well. I am who I am because of all of the life lessons that you have taught me. There is no way that I could have accomplished what I have without all of your support. Therefore, this is for all of you. 


\section{Acknowledgements}

First and foremost, I need to thank my advisor, Dr. Bradley Buckley. If it weren't for him, I would have never had the opportunity to do any of this. I applied, unsuccessfully, for four years to graduate programs around the country and Dr. Buckley was the only one who took a chance on me. I owe him a serious debt of gratitude that I can never repay or thank him enough for. Of course, I owe my committee members Drs. Sarah Eppley and Jason Podrabsky a huge debt of thanks as well. They have been so helpful with troubleshooting, with my writing and understanding when my projects changed over and over again. Thank you to my laboratory mate, Isaac Sleadd, and my laboratory manager, Marissa Lee, for helping me troubleshoot so many different problems with my western blots. I owe a huge thanks to all of the Raytheon and Lockheed Martin contractors at McMurdo station. Of course, my none of my research could have been accomplished if it were not for my amazing funding sources so a special thanks to the Sigma Xi foundation for awarding me my grant, G20110315156874, to the Portland State University Forbes Lea foundation for helping to fund my research, and to the National Science Foundation under NSF grant ANT-0944743 to B.A.B. A special thanks to Alison "Sandwich" Barden and Sarah Cancellieri for all of their help and support. Finally, and most importantly I must thank my family. Thank you all so much for being there for me when I needed you the most. 


\section{Table of Contents}

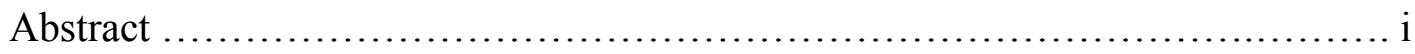

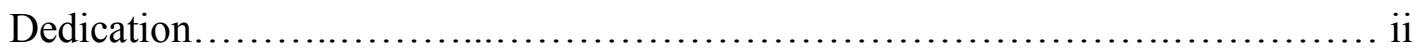

Acknowledgements................................................... iii

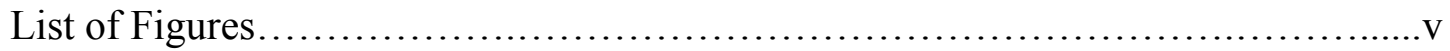

Chapter 1: Overview and background.................................... 7

Chapter 2: The CCAAT/enhancer binding protein- $\delta(\mathrm{C} / \mathrm{EBP}-\delta)$ and its expression in hypoxia-stressed zebrafish, Danio rerio............................ 14

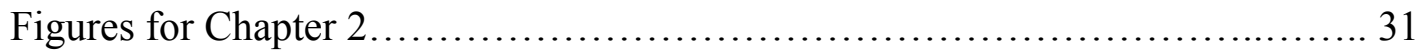

Chapter 3: Gadd45- $\alpha$ expression in heat-shocked liver tissue from an Antarctic notothenioid fish, Trematomus bernacchii.................................37

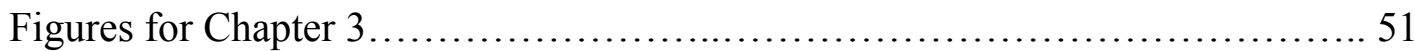

Chapter 4: Conclusions.............................................. 54

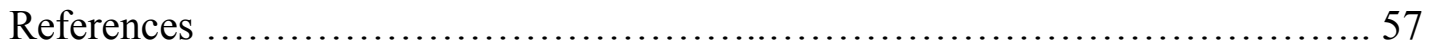

Appendix............................................................... 71 


\section{List of Figures}

Figure 1 a. Representative trace of oxygen consumption during respirometry experiment.

Figure 1 b. Representative pCrit of zebrafish, Danio rerio determined using a custom respirometry chamber. Averages of six experiments yielded a pCrit of $20.67 \%$ (standard deviation, 4.446; minimum and maximum were $14.43 \%$ and $26.21 \%$ respectively).

Figure 2. Diagram of hypoxia experimental tank setup.

Figure 3 a. Oxygen saturation in control and experimental (hypoxia) tanks throughout the duration of experiment one.

Figure 3 b. Oxygen saturation in control and experimental (hypoxia) tanks throughout the duration of experiment two.

Figure 4. C/EBP- $\delta$ expression in relative densitometry units for control and hypoxia exposed zebrafish white muscle at zero, two and four hour time points from trial one.

Figure 5. C/EBP- $\delta$ expression in relative densitometry units for control and hypoxia exposed zebrafish white muscle at zero, two and four hour time points from trial two.

Figure 6. C/EBP- $\delta$ expression in relative densitometry units for control and hypoxia exposed zebrafish white muscle at zero, two and four hour time points after results from trial one and two were pooled.

Figure 7. The Antarctic emerald rockcod, Trematomus bernacchii (photo courtesy of A. Barden). 
Figure 8. Ross Island in McMurdo Sound Antarctica. Red box denotes Erebus Bay, location of the three samples sites for the study (Map courtesy of M. LaRue of the Polar Geospatial Center).

Figure 9. Gadd45- $\alpha$ expression in isolated liver tissue from Trematomus bernacchii that was exposed to either $-2^{\circ}, 2^{\circ}, 6^{\circ}$ or $10^{\circ} \mathrm{C}$ for a range of durations. 


\section{CHAPTER 1: Overview and Background}

This thesis is the culmination of two years of research on the cellular stress response (CSR) in two teleosts: a genetic model species, the zebrafish (Danio rerio) and an extremely cold-adapted, stenothermic Antarctic fish (Trematomus bernacchii). The studies described here investigated two molecular mechanisms within the larger context of the cellular stress response (CSR). My research focused on alterations in protein expression during exposure to acute, non-lethal environmental stressors. In the zebrafish, I examined the production of CCAAT/enhancer binding protein-delta $(\mathrm{C} / \mathrm{EBP}-\delta)$ in the zebrafish during hypoxic stress while in T. bernacchaii I examined patterns of expression of growth arrest and DNA damage $45-\alpha$ protein (gadd45- $\alpha$ ) during a range of heat stresses. Each of these studies is presented in detail in the following chapters. However, in order to better describe the outcomes and possible implications of these studies, it is important to first provide an overview of what research has been done in the past to lead us to the questions we have sought to answer. Therefore, I will first start by describing the evolution of the CSR and some of its main components.

Kültz (2003) defines cellular stress as damage or the possibility of damage to macromolecules. The CSR is a general characteristic of all cells and is involved in a myriad of cellular processes including cell cycle control, protein chaperoning/repair, DNA repair and removal of damaged DNA (Kültz, 2003). The likely reason the CSR is so highly conserved is because environmental change and instability has influenced the evolution of life since it first began (Chippindale, et al., 1998). For the first unicellular organisms to cope with different environmental stressors on a constant basis, they 
developed a CSR as a defense mechanism in order to deal with abiotic insults (Kültz, 2005). One of the most immediate cellular responses to heat exposure, hypoxia and other abiotic stressors is the adaptive modulation of gene expression (Van Straalen and Roelofs, 2006). Stress-responsive genes must be rapidly induced and, upon return to homeostatic conditions, rapidly down-regulated (Gasch et al., 2000; Roelofs et al., 2010). This precise regulation is controlled by transcription factors, which are produced or become activated in response to exposure to environmental stressors. Many of the proteins involved in the CSR are among the most highly conserved proteins in all organisms (Kültz, 2003). In fact, the cellular stress response genes encode $18 \%$ of the most structurally and functionally conserved proteins among the three super-kingdoms (Kültz, 2003). However, these highly conserved CSR proteins are not just expressed during stressful situations; many are also involved in basic cellular functions, suggesting that the CSR was developed very early on in cellular evolution to provide a buffer for cells against Earth's harsh environment (Waters, 1995; Feder and Hofman, 1999; Kültz, 2003).

One major aspect of the CSR that has been studied extensively is how organisms respond to thermal stress both at the whole organism level and at the cellular level (Hofmann et al., 2000; Buckley et al., 2001; Buckley and Hofmann, 2002; Hofmann et al., 2002; Buckley et al., 2004; Buckley and Hofmann, 2004; Buckley et al., 2006; Buckley and Somero, 2009; Castilho et al., 2009). Hyperthermia can cause proteins to lose their tertiary and quaternary structures and DNA to become susceptible to replication errors and more prone to mutations. However, organisms have evolved effective ways to survive and thrive in even the most extreme conditions. One of the best-studied 
components of the CSR to date is the heat-shock protein (Hsp) suite of genes and protein products (Feder and Hofman, 1999). The Hsps are a class of molecular chaperones, which are involved in many aspects of cellular function from the prevention of protein aggregation to the protection of macromolecules, cells, tissues and organisms from abiotic stresses (eg. heat-shock) (Fink, 1999; Waters et al., 1996). The genes that code for Hsps are highly conserved. They occur in every species in which they have been sought and across all organismal kingdoms (Lindquist, 1986; Feder and Hofmann, 1999; Krebs and Bettencourt, 1999; Kültz, 2003). The discovery of Hsps in other organisms is no longer novel (Feder and Hofman, 1999); however, understanding the mechanisms of how Hsps function and how they have evolved and are continuing to evolve continues to be the subject of cutting-edge research.

Environmental stress acts as a selective pressure to which organisms must adapt, leading to tolerant/resistant populations (Roelofs et al., 2007). Therefore, organisms that live highly variable environments, such as the goby, Gillichthys mirabilis, which lives in the intertidal zone which has large fluctuations in daily temperatures, or the annual killifish, Austrofundulus limnaeus, which has its ephemeral ponds dry up each year, will have more selective pressure to rapidly up- and down- regulate their CSR elements (Podrabsky and Somero, 2004; Gracey et al., 2010). The same CSR elements will perhaps not have been selected for in organisms that have evolved in stable environments, leaving the genes that encode these elements exposed to mutation and drift. A possible example of this is the expression of Hsp70 in the cold-adapted Antarctic emerald rockcod, Trematomus bernacchii (Hofmann et al., 2000). As stated before, the Hsp genes and proteins have been found in every super-kingdom and every species in 
which they have been sought. However, in T. bernacchii, the expression of Hsps due to heat-shock is not as clear and defined (Hofmann et al, 2000; Buckley et al, 2004). Exposure to temperatures well above the organismal thermotolerance range of this species $\left(\sim 6^{\circ} \mathrm{C}\right.$ to $10^{\circ} \mathrm{C}$; Somero and DeVries, 1967) do not induce additional Hsp70 accumulation (Hofmann et al., 2000). It is now clear that these cold-adapted species express Hsps in a constitutive manner, perhaps due to problems folding protein in the cold (Buckley et al., 2004; Place and Hofmann, 2005; Buckley and Somero, 2009). Despite lacking an inducible HSR, T. bernacchii does possess the ability to up- and down-regulate the expression of hundreds of genes in response to sub-lethal thermal stress (Buckley and Somero, 2009).

Hsps are not the only cytoprotective proteins and heat shock is not the only environmental stressor that cells encounter. Having a set of cytoprotective mechanisms onboard to respond to different stressors is important for organisms to survive in both variable and extremely stable environments, such as the waters of continental Antarctica. Cells have developed several different ways in which they cope with environmental stressors and their effects on macromolecular molecules. Several of these mechanisms include activating genes encoding proteins involved in DNA repair mechanisms (Sluyser, 2005), cell cycle arrest (Buckley et al., 2006), and programmed cell death, termed apoptosis (Herr and Debatin, 2001). The advent of genomic techniques such as transcriptional profiling with cDNA microarrays has allowed for the expression of thousands of genes to be measured simultaneously. cDNA microarray studies have revealed that one gene was always strongly induced in the tissues of heat-stressed fishes, including T. bernacchii (Buckley and Somero, 2008), the goby (Gillichthys mirabilis) 
(Buckley et al., 2006), the bluefin tuna (Thunnus orientalis ) (Castilho et al., 2009) and the zebrafish (Danio rerio) (Buckley, unpublished data). That gene is the $c / e b p-\delta$ gene which encodes the CCAAT/enhancer binding protein- $\delta(\mathrm{C} / \mathrm{EBP}-\delta)$, one of the target proteins of my thesis.

$\mathrm{C} / \mathrm{EBP}-\delta$ is part of a family of $\mathrm{C} / \mathrm{EBP}$ proteins, which are all basic region leucine zipper (bZip) transcription factors (Ramji and Foka, 2002). These proteins influence cell fate by forming homo- or heterodimers with other members of this family and other bZipcontaining proteins (Johnson, 2005). Nearly all of the work on C/EBP- $\delta$ has been done in studies on cancer cells (Tang et al., 2005; Porter et al., 2001) and this protein has shown potential to be used as an anti-cancer agent as it is highly induced during $\mathrm{G}_{0}$ growth arrest in these cancer cell lines (O’Rourke, Hutt and DeWille, 1999; Porter et al., 2001; Sivko and DeWille, 2004; Tang et al., 2005). While research on C/EBP- $\delta$ continues in the field of cancer biology, its role in other cells and ectothermic organisms has not been as welldefined. By using model and non-model species to study the effect of environmental stress on the expression of this gene, we will better understand its function in normal cell types, with the goal of building a better understanding of how it functions in the general CSR and what its role is in inducing growth arrest and or apoptosis.

As stated above, C/EBP- $\delta$ was shown to be up-regulated in $T$. bernacchii under heat stress with a cDNA microarray study (Buckley and Somero, 2009). Recently, it has been shown that not only is $\mathrm{C} / \mathrm{EBP}-\delta$ up-regulated in white muscle and spleen tissues during heat stress, but also that $\mathrm{C} / \mathrm{EBP}-\delta$ is constitutively expressed in field-caught individuals as well (Sleadd and Buckley, in press). This latter finding is similar to that found in previous studies on Hsps in Antarctic fish (Hofmann et al., 2000; Place and 
Hofmann, 2005). Therefore, in addition to its cell cycle regulatory role, C/EBP- $\delta$ may also be involved in general housekeeping functions under non-stressful conditions.

As with many proteins involved in the CSR, C/EBP- $\delta$ may be involved in responding to stressors other than extreme heat. While Hsps are best known for their role in response to heat shock (Feder and Hofmann, 1999), Hsps are also up-regulated during exposure to other environmental stressors such as hypoxia (Ferrieo et al., 1990). Since Hsps are up-regulated as more of a general response to stress rather than to a specific stressor, we hypothesized that $\mathrm{C} / \mathrm{EBP}-\delta$ may also be inducible by a variety of environmental stressors. To test this idea, I examined whether C/EBP- $\delta$ is up-regulated during hypoxia stress in a genetic model species, the zebrafish (D. rerio).

Gadd45- $\alpha$ is another protein that has been implicated in cell cycle regulation during environmental stress is the growth arrest and DNA damage protein 45- $\alpha$ (gadd45- $\alpha$ ). Gadd45 genes function as stress sensors involved in the response of cells to physiological stressors and in tumor formation (Fornace et al., 1992; Liebermann, D.A. and Hoffman, 2002). Gadd45 proteins interact with stress-responsive proteins including PCNA, p21 and p38 kinase and it has been shown to cause cell cycle arrest at the $\mathrm{G}_{2} / \mathrm{M}$ phase in response to both genotoxic and environmental stress in nearly all mammalian cells tested to date (Fornace et al., 1988; Kastan et al., 1992; Fornace et al., 1989). However, its responsiveness to thermal stress is still relatively unexplored. Given the unique thermal physiology of the cold-adapted Antarctic fishes and my interest in linking heat stress to expression of cell cycle regulators, I examined the effect of elevated temperature on levels of gadd45- $\alpha$ in the liver tissue of $T$. bernacchii collected from the frigid waters of McMurdo Sound, Antarctica and exposed to heat in the laboratory. 
In summary, this thesis examines CEBP- $\delta$ in hypoxia-stressed zebrafish and gadd45- $\alpha$ in heat-shocked T. bernacchii in order to continue to elucidate the mechanisms by which the CSR functions and which genes/proteins are involved. The over-arching goal is to further our understanding of how the effects of environmental stressors are manifested at the cellular level and to build a more complete picture of the genetic underpinnings of the CSR. 


\title{
CHAPTER 2: The CCAAT/enhancer binding protein- $\delta(C / E B P-\delta)$ and its expression in hypoxia-stressed zebrafish, Danio rerio.
}

\begin{abstract}
The CCAAT/enhancer-binding protein $\delta(\mathrm{C} / \mathrm{EBP}-\delta)$ is an important transcription factor in vertebrates and a critical mediator of cell proliferation and differentiation. $\mathrm{C} / \mathrm{EBP}-\delta$ has been implicated in inflammatory and stress responses, as well as growth arrest in certain cancer cell lines. $\mathrm{C} / \mathrm{EBP}-\delta$ has also been shown to be a pro-apoptotic gene regulator and therefore has strong potential for use as an anti-cancer agent. At both the mRNA and protein levels, $c / e b p-\delta$ expression has been shown to be responsive to temperature in a variety of ectotherms. Apart from heat stress, the role of C/EBP- $\delta$ has not been extensively investigated with regard to other environmental stressors.

This study investigated the proposed link between hypoxia stress and C/EBP- $\delta$ protein levels using the genetic model fish species, Danio rerio. The critical oxygen tension (pCrit) was experimentally determined to be $20.67 \%$ oxygen saturation (SD, 4.446; min and $\max , 14.43 \%$ and $26.21 \%$ ). Zebrafish were exposed to $10 \%$ oxygen saturation for four hours. Two identical hypoxia experiments were run on separate days. Trial one showed a significant effect of time $(\mathrm{P}=0.014)$ while trial two showed a significant effect of treatment $(\mathrm{P}=0.042)$. In both trials there was a significant interaction between treatment and exposure time (trial 1, $\mathrm{P}=0.0003$; trial 2, $\mathrm{P}=0.01$ ). After pooling the two trials together, the interaction between exposure time and treatment remained $(\mathrm{P}=0.002)$, and the effect of time from trial one returned $(\mathrm{P}=0.013)$, while the effect of treatment from trial two no longer was present $(\mathrm{P}>0.05)$. C/EBP- $\delta$ was expressed constitutively in zebrafish white muscle tissue in both control and hypoxia exposed
\end{abstract}


individuals. These complex results and interactions suggest that C/EBP- $\delta$ may not be upregulated in response to hypoxia. 


\section{Introduction}

Environmental change and instability has influenced the evolution of life since it first began (Chippindale, et al., 1998). For the first unicellular organisms to cope with different environmental stressors on a constant basis, they developed a cellular stress response (CSR) as a defense mechanism in order to deal with abiotic insults (Kültz, 2005). Many of the proteins involved in the CSR are among the most highly conserved proteins in all organisms (Kültz, 2003). In fact, the cellular stress response genes encode $18 \%$ of the most structurally and functionally conserved proteins among the three superkingdoms (Macario et al., 1999; Hecker and Volker, 2001; Feder and Hofmann, 1999; Pearce and Humphrey, 2001). However, these highly conserved CSR proteins are not just expressed during stressful situations; many are involved in basic cellular functions, suggesting that the CSR was developed very early on in cellular evolution (Waters, 1995; Feder and Hofmann, 1999; Kültz, 2003).

The CSR involves cellular responses to many different environmental stressors (Kültz, 2005). With regard to oxidative stress, indirect evidence suggests that oxygen sensors may be common to all cells (Bunn et al., 1988). This suggests that oxidative stress has been a problem that organisms have dealt with for as long as organisms have relied on oxygen in metabolic reactions. Several studies have shown extensive gene expression changes in telelosts exposed to hypoxic stress. For example, Gracey et al. (2001) showed a large-scale transcriptional response to hypoxia in G. mirabilis including the upregulation of genes involved in anaerobic ATP production as well as a down regulation of energy requiring pathways. Also, Ton et al. (2003) identified 138 genes in D. rerio responsive to hypoxia, which were also involved in anaerobic metabolism and 
energy conservation. These findings suggest that many genes are involved in the cytoprotective CSR to hypoxia. Low oxygen levels play major roles in clinical conditions including heart failure and stroke (Marques et al., 2008). Therefore, a better understanding of the mechanisms that are involved in mitigating the effect of hypoxia stress also has strong biomedical implications.

The CCAAT/enhancer binding protein-delta (CEBP- $\delta$ ) is an important transcription factor in vertebrates and a critical mediator of cell proliferation and differentiation (O'Rourke et al., 1999; Johnson, 2005). C/EBP- $\delta$ has been implicated in inflammatory and stress responses, as well as growth arrest in certain cancer cell lines (Thangaraju et al., 2005). C/EBP- $\delta$ has also been shown to be a pro-apoptotic gene regulator (Thangaraju et al., 2005). While C/EBP- $\delta$ has been shown to be involved in the cellular response to various stress stimuli and is up-regulated during heat shock (Buckley et al., 2006; Buckley, 2009; Sleadd and Buckley, in press), its response to hypoxic stress has yet to be determined.

While the entire pathway for C/EBP- $\delta$ has yet to be published, a relatively wellestablished pathway for C/EBP- $\delta$ has been shown in mammalian systems involving STAT-3 (Clarkson et al., 2006). It has been shown that the induction of C/EBP- $\delta$ in mammalian epithelial cells treated with the pro-inflammatory cytokine interleukin 6 (IL6) is dependent upon a signaling pathway that includes phosphorylated STAT-3 (Cantwell et al., 1998). Recently, a STAT-3 binding site, acute phase response element (APRE), was identified in the $5^{\prime}$ untranslated region of the $c l e b p-\delta$ gene from the goby $G$. mirabilis (Buckley, 2011). This finding suggests that C/EBP- $\delta$ is regulated through a STAT-3 pathway. In the same study, three hypoxia response elements (HREs) were 
identified in the $5^{\prime}$ untranslated region of the $c / e b p-\delta$ gene as well (Buckley, 2011). Hypoxia inducible factor-1 $\alpha$ (HIF-1 $\alpha)$ is a highly conserved transcription factor that becomes active under oxygen limitation (Vaupel, 2004). Active HIF-1 $\alpha$ binds to HREs and induces the expression of a suite of genes that are involved in a range of cellular processes. Therefore, it is possible that HIF-1 $\alpha$ is an upstream regulator of $c / e b p-\delta$ in fishes and potentially in other organisms as well. Given the established roles of C/EBP- $\delta$ in mammalian systems (Johnson, 2005), it is possible that in response to hypoxic stress, increased concentrations of C/EBP- $\delta$ protein could inhibit cell division as a cytoprotective measure, and, if enough macromolecular damage occurs, apoptosis will ensue.

The zebrafish, Danio rerio, is an excellent model for scientific research. The zebrafish has been used extensively in research on vertebrate development because its embryos are relatively large, robust, transparent, and develop rapidly, allowing researchers to visualize changes in development over a short time period (Dahm, 2006). Due to the extensive used of the zebrafish as a model organism, its entire genome has been mapped and sequenced, making it a strong candidate for the study of the genetic bases of functional traits (Briggs, 2002). Finally, the zebrafish genome has a high homology to the human genome, which allows results from zebrafish studies to be translatable to human studies (Lieschke and Currie, 2007).

Since the role of C/EBP- $\delta$ in response to hypoxia has not yet been elucidated, I employed the zebrafish as a model organism to investigate whether C/EBP- $\delta$ levels varied in response to hypoxia and to test whether the duration of exposure affected the concentration of this protein. As hypoxia is known to be stressful for cells (Kültz, 2003), 
mechanisms to control cellular energy used should be up-regulated in response to stressful levels of hypoxia in order to reallocate energy resources to cytoprotective mechanisms (Kültz, 2005). HIF-1 $\alpha$ is one of the main transcription factors involved in response to hypoxia (Vaupel, 2004). Due to the HREs found in the clebp- $\delta$ (Buckley, 2011) which HIF-1 $\alpha$ binds to, and the role that C/EBP- $\delta$ has in halting the cell cycle to conserve energy for cytoprotective mechanisms, I hypothesized that C/EBP- $\delta$ would be responsive to non-lethal hypoxic stress. Here, I investigated the hypoxia-responsiveness of this gene by measuring $\mathrm{C} / \mathrm{EBP}-\delta$ protein levels in brain and white muscle tissue of the zebrafish, Danio rerio during acute hypoxic stress. 


\section{Materials and methods}

Animal collection and care

Wild type mixed sex zebrafish and supplies were purchased from a local pet store (The Wet Spot, Portland, OR). C/EBP- $\delta$ is a highly conserved transcription factor,and without the $c / e b p-\delta$ gene and protein functioning properly, organisms would not develop properly and not grow into adults. Therefore, no matter what kind of zebrafish I used (males, females, fish with known lineages, etc.), C/EBP- $\delta$ should respond in a similar pattern. Organisms were housed in one of three, 10-gallon aquaria and kept at $28.5^{\circ} \mathrm{C}$. Water in the aquaria was UV treated nano pure water enriched with Instant Ocean brand synthetic sea salt at 0.3 parts per thousand. Marineland Penguin BIO-Wheel brand power filters were run constantly to ensure water freshness. Filters were rinsed off once a week or more if needed. Partial water changes (approximately $1 / 4$ of the tank) were performed weekly or more if needed to prevent the buildup of excess waste in aquarium water. Nitrite/Nitrate levels and $\mathrm{pH}$ of water was tested three times a week (Monday, Wednesday and Friday) using Aquarium pharmaceuticals brand $\mathrm{pH}$ and nitrite/nitrate test kits. Fish were fed Top Fin Tropical Flake brand flake fish food three times a week (Monday, Wednesday and Friday). Fish were not fed at least 48 hours prior to being used for an experiment. All experiments were conducted according to University-approved IACUC protocols.

pCrit determination

In order to determine critical oxygen tension (pCrit) for zebrafish, I first ran a $\mathrm{pCrit}$ experiment (Richards, 2009). The night before the experiment, one previously untested zebrafish was chosen at random from an aquarium and placed in a modified respirometry 
chamber. This chamber consisted of a $5 \mathrm{~mL}$ syringe (without plunger) connected to a pump with measured tubing. The tubing had a measured volume of $14.2 \mathrm{~mL}$. Overnight, the fish was allowed to acclimate to the chamber and conditions. Water was kept at $25^{\circ} \mathrm{C}$ as the respirometry chamber is owned by the Podrabsky laboratory and normally used for killifish. Fresh air was constantly bubbled into the chamber overnight and $\mathrm{O}_{2}$ concentration was kept at $100 \%$. The next morning, the air pump was turned off and the amount of respired oxygen in the chamber was measured. Respirometry data was measured with LabChart \& Scope software (AD instruments). Data collection was stopped when the fish turned on its side or upside down. The fish was immediately removed from the respirometry chamber and placed into a beaker with $100 \% \mathrm{O}_{2}$ saturation (Figure $1 \mathrm{a}$ ).

Hypoxia experiment

Two 10-gallon aquaria were modified by securing two walls of strong plastic mesh to the short sides of each aquarium with silicon. A water pump and an air stone was placed behind each wall. The thick mesh walls prevented the air bubbles from creating excessive turbulence in the water so as to not add an extra stress to the fish. The pump pulled water from the bottom of the tank and pumped it closer to the surface. Pumps were placed in opposite corners of the tank to ensure maximal mixing of water. In the control tank, the air stones were attached to pumps, which provided $100 \% \mathrm{O}_{2}$ saturation of the water. The air stones in the hypoxia tank were connected to a solenoid valve, which was connected to a nitrogen gas tank. Both tanks also had waterproof $\mathrm{O}_{2}$ sensors suspended near the surface to measure $\mathrm{O}_{2}$ saturation of the water. The hypoxia $\mathrm{O}_{2}$ sensor in the hypoxia tank was interfaced with the solenoid valve connected to the nitrogen gas tank. 
The interface was set to allow nitrogen gas to be pumped into the tank until $\mathrm{O}_{2}$ saturation of the water reached $9.5 \%$. Once this level was reached, the solenoid valve would close, allowing the $\mathrm{O}_{2}$ saturation to slowly rise. Once it reached $10.5 \%$, the solenoid valve would again open, lowering the $\mathrm{O}_{2}$ saturation back to $9.5 \%$. This method allowed the average $\mathrm{O}_{2}$ saturation to remain at $10 \% \pm 0.5 \%$. A level of $10 \% \mathrm{O}_{2}$ saturation was chosen as the hypoxia set point for several reasons. $10 \%$ was below the pCrit that I measured using my respirometry data and would therefore lead to a stressful environment for the fish yet not so stressful that it would be lethal. After I conducted the pCrit experiment and before I conducted the hypoxia experiment, I chose 4 fish at random and observed them for six hours in the $10 \% \mathrm{O}_{2}$ saturation condition. During this time, none of the fish died. Lastly, $10 \% \mathrm{O}_{2}$ saturation is a non-lethal level that has been used in previous acclimation studies which showed changes in gene expression and physiological function (Rees et al., 2001; Bosworth et al., 2004; van der Meer et al., 2005; Marques et at., 2007) (Figure 2).

The night before the hypoxia experiment was conducted, fish were selected at random and placed into either the control or hypoxia tanks. Both tanks were held at $28.5^{\circ} \mathrm{C}$ and had $100 \% \mathrm{O}_{2}$ saturation before the fish were introduced. The fish were allowed to acclimate to their new surroundings for at least 16 hours. Before the nitrogen gas was turned on for the hypoxia tank, six individuals at the 0 hour were removed from both tanks, wrapped in a sheet of labeled tin foil, and flash frozen in liquid nitrogen. Then the nitrogen gas was turned on. It took 10 minutes and seven minutes in the two experiments respectively for the $\mathrm{O}_{2}$ saturation to drop from $100 \%$ to $9.5 \%$ (Figures 3 a and $3 \mathrm{~b}$ ). $\mathrm{O}_{2}$ saturation did not fluctuate above $10.5 \%$ or below $9.5 \%$ during the duration of the experiment (Figures 3 a and 3 b). At hours 2 and 4, individuals were removed from 
both the control and hypoxia tanks, wrapped in a sheet of labeled tin foil, and flash frozen in liquid nitrogen, and stored at $-80^{\circ} \mathrm{C}$ until use. This experiment was run two separate times on different dates.

\section{Tissue preparation}

Individual organisms were thawed on ice and white muscle tissue samples were removed. Samples were homogenized in lysis buffer containing 10\% sodium dodecyl sulfate (SDS), and $0.032 \mathrm{~mol}$ TRIS. Samples were incubated at $100^{\circ} \mathrm{C}$ for 5 minutes, and centrifuged at $13,500 \times \mathrm{g}$ for 20 minutes to remove cellular debris. Protein content of the $13,500 \times \mathrm{g}$ supernatants was determined using a modified Bradford assay and samples were stored at $-80^{\circ} \mathrm{C}$ until use.

Polyacrylamide gel electrophoresis (PAGE)

Prepared samples were electrophoresed on $8.3 \mathrm{~cm} \times 7.5 \mathrm{~cm}, 0.75 \mathrm{~mm}, 10 \%$ SDSTris-glycine polyacrylamide gels. Each tube was loaded with a sample with a protein concentration of $15 \mu \mathrm{g} / \mu \mathrm{L}$ and a lysis buffer volume to total $10 \mu \mathrm{L} .10 \mu \mathrm{l}$ of $2 \times$ SDSPAGE sample buffer was added to each sample. Finally all samples were heated for three minutes at $100^{\circ} \mathrm{C}$ and each entire sample was electrophoresed at $130 \mathrm{~V}$ for 1.5 hours.

\section{Custom C/EBP- $\delta$ antibody production}

The custom C/EBP- $\delta$ antibody was manufactured in rabbit using a peptide corresponding to a 15-aa sequence from the N terminus region of the Gillichthys mirabilis $\mathrm{C} / \mathrm{EBP}-\delta$ protein as an antigen (Affinity BioReagents, Rockford, IL, USA). Protein concentration determination via immunoblotting (western blotting)

Nitrocellulose membranes $(0.2 \mu \mathrm{m}, \mathrm{BIO}-\mathrm{RAD})$ were soaked in nano-water for 30 minutes, one hour prior to transfer assembly. Transfer was conducted overnight at $30 \mathrm{~V}$. 
Following transfer, membranes were blocked for one hour in 5\% non-fat milk dissolved in $1 \mathrm{x}$ Phosphate Buffered Saline (PBS) with gentle agitation. Following blocking, membranes were incubated in a 1:1,000 dilution of a custom Gillichthys mirabilis C/EBP- $\delta$ anti-rabbit polyclonal antibody diluted in milk block for 1.5 hours at room temperature. Following incubation, membranes were washed three times for 10 minutes per wash in a $1 \times$ PBS $+0.1 \%$ TWEEN solution. Next, membranes were incubated in a 1:10,000 dilution of a goat-anti-rabbit polyclonal antibody diluted in milk block for one hour at room temperature. Membranes were washed six times for five minutes per wash in $1 \times$ PBS $+0.1 \%$ TWEEN .

Membranes were soaked in four $\mathrm{mL}$ of Chemiluminescent solution (Thermo Scientific Super Signal West Pico Chemiluminescent Substrate) for five minutes. Membranes were then wrapped in plastic wrap and placed in developing cassette (Four Square). The membranes were exposed to x-ray film (Thermo Scientific CL-X Posure Film). Band intensity from individual blots was measured by ImageJ. Band size and intensities of samples were compared to an internal standard that was loaded onto each gel. For a list of all tissues and antibodies tested, see Appendix.

\section{Statistics}

To determine the pCrit, 10 minute averages were taken of the $\mathrm{VO}_{2}$. Data were analyzed using a non-linear regression using GraphPad Prism software (GraphPad Software, Inc., La Jolla, CA, USA). Each hypoxia experimental trial was analyzed independently using a 2-way ANOVA. Both data sets were pooled and re-analyzed via two-way ANOVA on the pooled data for both trials. Differences between values at a given time point were determined via post-hoc Bonferroni correction using GraphPad 
Prism software. 


\section{Results}

pCrit determination

Averaging the pCrit obtained from six individual experiments yielded a pCrit of $20.67 \%$ (standard deviation, 4.446; minimum and maximum were $14.43 \%$ and $26.21 \%$ respectively) (Figure 1 b).

\section{$C / E B P-\delta$ concentration}

In trial one, there was no significant effect of treatment $(\mathrm{df}=1 ; \mathrm{P}>0.05)$ while there was a significant effect of exposure time $(\mathrm{df}=2 ; \mathrm{P}=0.014)$. For this trial, there was a statistically significant interaction between treatment and exposure time $(\mathrm{df}=2 ; \mathrm{P}=0.003)$ (Figure 4). In trial two ( $\mathrm{n}=6$ for all treatments and time points), there was a significant effect of treatment $(\mathrm{df}=1 ; \mathrm{P}=0.042)$ but not of exposure time $(\mathrm{df}=2 ; \mathrm{P}>0.05)$. Again, in trial two as in trial one, there was a statistically significant interaction between treatment and exposure time $(\mathrm{df}=2 ; \mathrm{P}=0.01)$ (Figure 5). When the two data sets were pooled, the data show that there was a statistically significant interaction between exposure time and treatment $(\mathrm{df}=2 ; \mathrm{P}=0.002)$ and that the effect of exposure time was statistically significant $(\mathrm{df}=2 ; \mathrm{P}=0.013)$. There was no significant effect of treatment on $\mathrm{C} / \mathrm{EBP}-\delta$ levels $(\mathrm{df}=1 ; \mathrm{P}>0.05)$ (Figure 6). C/EBP- $\delta$ was expressed constitutively in control individuals at all time points during all trials. 


\section{Conclusion}

Hypoxia occurs over large areas in aquatic systems worldwide, and can have deleterious affects on aquatic animals, perhaps leading to population decline and changes in community by eliminating sensitive species (Shang and $\mathrm{Wu}, 2004)$. However, there are many aspects of how cells respond to hypoxia have yet to be examined. The effects of hypoxia on the concentration of $\mathrm{C} / \mathrm{EBP}-\delta$ in zebrafish white muscle tissue that were observed here were complex. Two hypoxia treatment trials were run on separate days and the outcomes of the trials differed from one another (Figures 4 and 5). While in both trials there was a significant effect of the interaction between the treatment and time, the effect of time of exposure to hypoxia on $\mathrm{C} / \mathrm{EBP}-\delta$ levels was only significant in trial one while the effect of treatment alone was only significant in trial two.

One potential reason that $\mathrm{C} / \mathrm{EBP}-\delta$ was not up-regulated during hypoxia in a consistent manner is that $10 \%$ may not have been a low enough $\mathrm{O}_{2}$ saturation. There was a substantial amount of individual variation during the pCrit testing phase; one individual showed a pCrit of $14.43 \% \mathrm{O}_{2}$ saturation while another individual showed a pCrit of $26.21 \% \mathrm{O}_{2}$ saturation. However, previous studies have shown that $10 \% \mathrm{O}_{2}$ saturation is low enough to elicit physiological changes and gene expression alteration (Rees et al., 2001; Bosworth et al., 2004; van der Meer et al., 2005; Marques et at., 2007). Perhaps a longer exposure time at $10 \% \mathrm{O}_{2}$ saturation is necessary to induce $\mathrm{C} / \mathrm{EBP}-\delta$. Another possible explanation is that while other CSR proteins are up-regulated during hypoxia, it is important to note that during bouts of hypoxia, most gene expression is diminished or shut down all together. Only the most essential genes/proteins will continue to be active under limited oxygen and it is possible that $\mathrm{C} / \mathrm{EBP}-\delta$ does not fall into this category. 
Lastly, it is important to remember that C/EBP- $\delta$ is a cell cycle regulator and the tissues I examined were brain and white muscle. Brain tissue did not cross-react with the custom C/EBP- $\delta$ antibody so I was only able to report results for white muscle tissue. Since all individuals tested were adults, it is possible that C/EBP- $\delta$ would be constitutively expressed in all of their white muscle cells. Being adults, they would not continue to grow in size by cell replication but rather by hypertrophy of each muscle cell individually. To control for this possibility, future studies should test tissue types that are know to divide (such as liver) and pool samples together or use larger experimental organisms so as to control for inter-individual variation and not have to pool samples.

While I did not obtain the results that I expected, this study is important nonetheless. Gaining a better understanding about how C/EBP- $\delta$ functions in the CSR has implications beyond fish ecophysiology. For example, since C/EBP- $\delta$ is a proapoptotic gene regulator (Thangaraju et al., 2005), a better understanding of its functionality could lead to its potential use as an anti-cancer agent. C/EBP- $\delta$ has been shown to have low levels of expression in human breast cancer cells (Porter, et al., 2003), however, induced expression of $\mathrm{C} / \mathrm{EBP}-\delta$ has lead to significant reductions in cell proliferation in both prostate and breast cancer cell lines (Ikezoe, et al., 2005). However, the way cancer cells respond to hypoxia, as opposed to other types of environmental stressors, can be slightly different. Many aggressive types of solid tumors have large areas that are significantly hypoxic compared to the rest of the tumor as well as healthy tissues. These hypoxic cells are resistant to many types of cancer therapies such as radiation and chemotherapy (Vaupel and Mayer, 2007). Approximately $90 \%$ of all known cancers are solid tumors (Brown, 2000). These types of tumors are able to alter their 
cellular micorenvironments in response to inadequate oxygen levels (Vaupel et al., 1989; and Ryan et al., 2000). HIF-1 $\alpha$ is involved in the regulation of genes that are responsive to low oxygen tension (Vaupel, 2004). Among these, changes in the expression of genes for erythropoietin, the angiogenic vascular endothelial growth factor (VEGF), transferrin recepors, and other proteins allow for the development of a more effective $\mathrm{O} 2$ (and nutrient) supply (Vaupel, 2004). While some of the effects of hypoxia negatively impact tumor cell growth (Vaupel and Harrison, 2004), they may eventually lead to hypoxiadriven responses that enhance tumor progression and aggressiveness, ultimately resulting in increased resistance to therapy and a poor long-term prognosis. A major goal in current cancer research is to categorize biological mechanisms that are involved in tumor development and progression and then design treatments and interventions that encompass that information. Elucidating the mechanisms by which C/EBP- $\delta$ is expressed, activated or functions with regards to cellular stress physiology could lead to a better understanding of how cancer cells function as well as lead to novel treatments.

Gaining a better understanding of the CSR through examining how normal cells respond during hypoxia could lead to better treatments and overall outcomes for patients with specific types of cancer. Future directions to better understand the role of $\mathrm{C} / \mathrm{EBP}-\delta$ should include determining how C/EBP- $\delta$ can be up-regulated in cancer cells. We know that heat stress causes an up-regulation of C/EBP- $\delta$ in fishes (Buckley et al., 2006; Buckley and Somero, 2009; Castilho, et. al. 2009; Sleadd and Buckley, in press); therefore, the next studies should not only determine if C/EBP- $\delta$ can be up-regulated in cancer cell lines in response to heat stress, but also determine if apoptosis can be induced. Also, as stated earlier, if a larger study organism and constantly dividing tissues are used 
to study the proposed link between $\mathrm{C} / \mathrm{EBP}-\delta$ and hypoxia, perhaps more consistent data will emerge. Further studies on the role of C/EBP- $\delta$ during hypoxia and other environmental stressors will help to broaden our knowledge of cell cycle regulating proteins as well as to determine how organisms respond at the cellular level to sub-lethal hypoxic stress. 


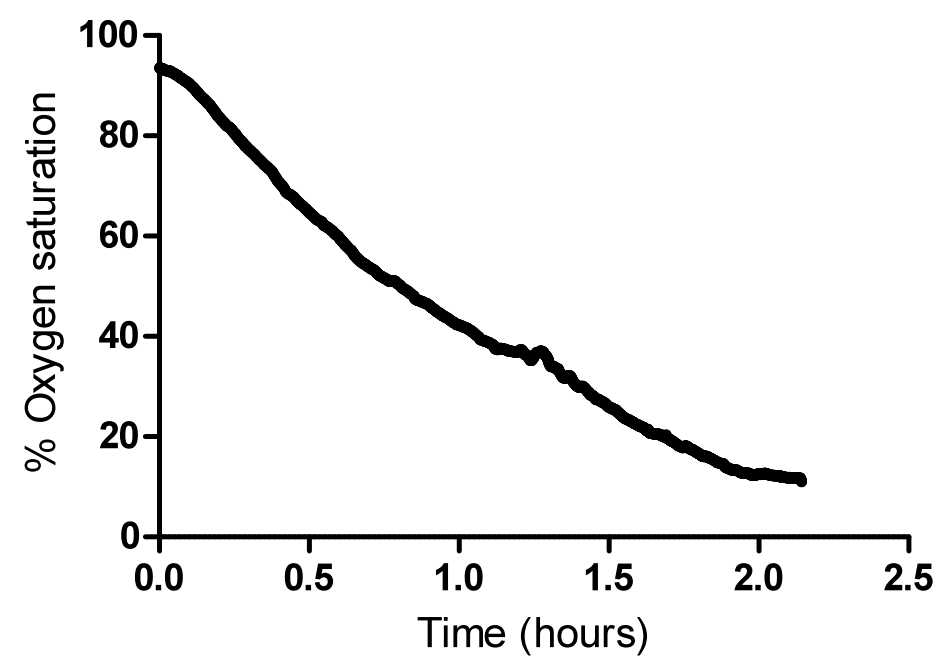

Figure 1 a. Representative trace of oxygen consumption during one respirometry experiment of one individual Zebrafish, Danio rerio.

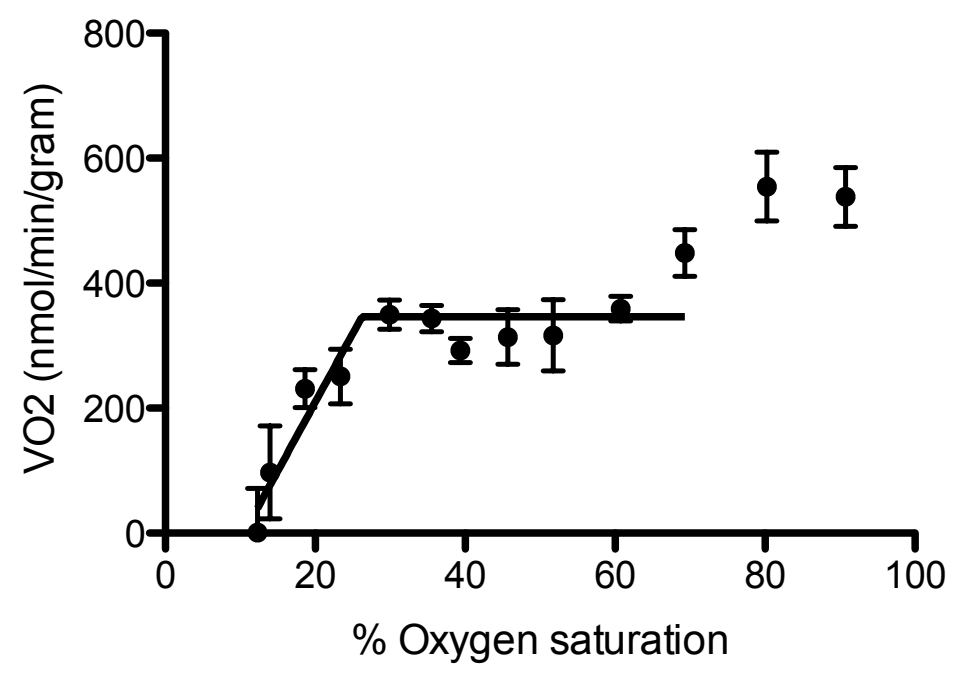

Figure $1 \mathbf{b}$. Representative pCrit from one zebrafish, Danio rerio determined using a custom respirometry chamber. Each data point represents a 10 minute average of $\mathrm{VO}_{2}$. 


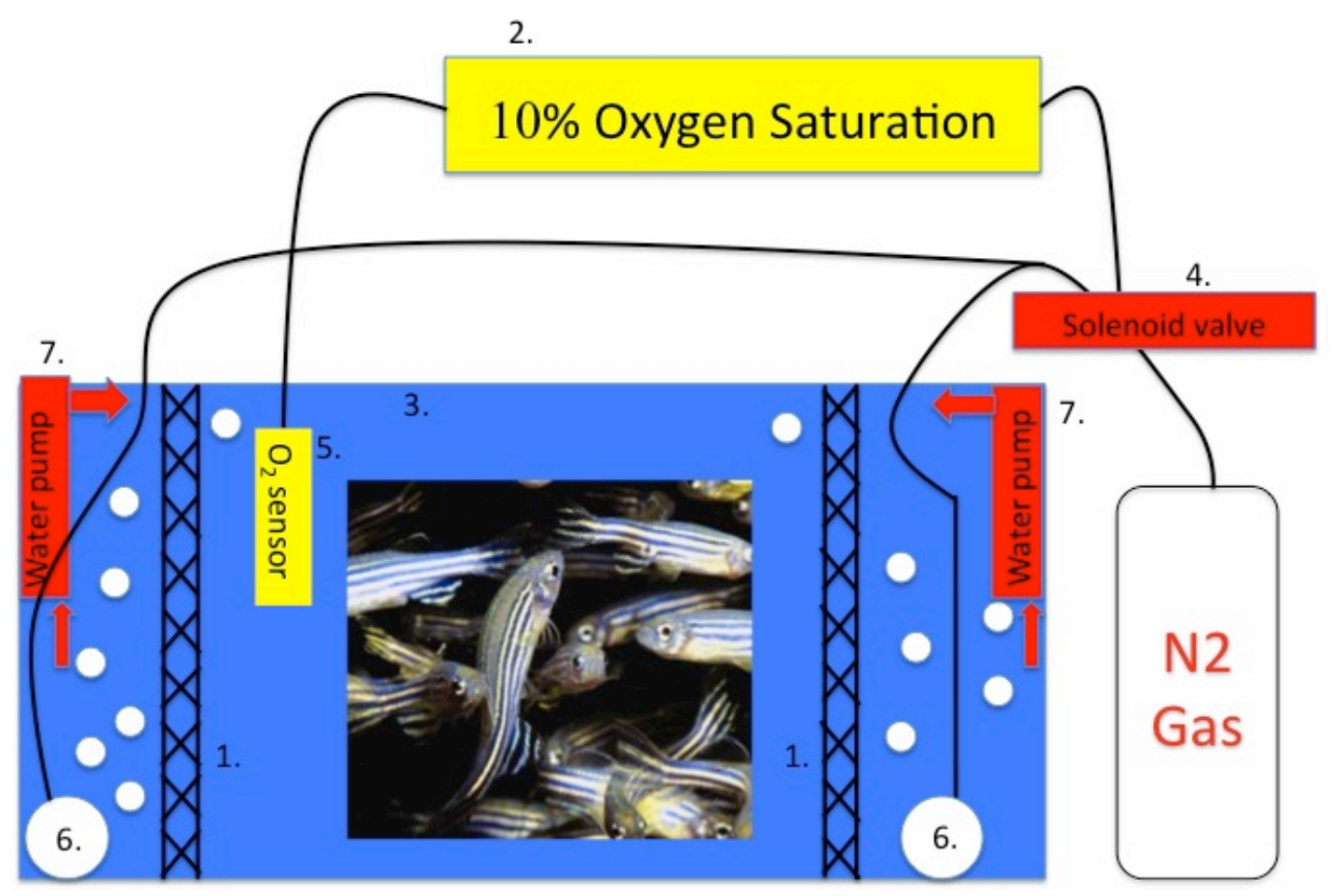

Figure 2. Schematic of hypoxia experimental setup. (1) Mesh barrier(s); (2) oxygen regulator; (3) adult hypoxia aquarium; (4) solenoid valve; (5) oxygen electrode; (6) air stone(s); (7) water pump(s). The compressed nitrogen source is shown as a white tank, and the nitrogen-containing gas tubes are marked with white. 


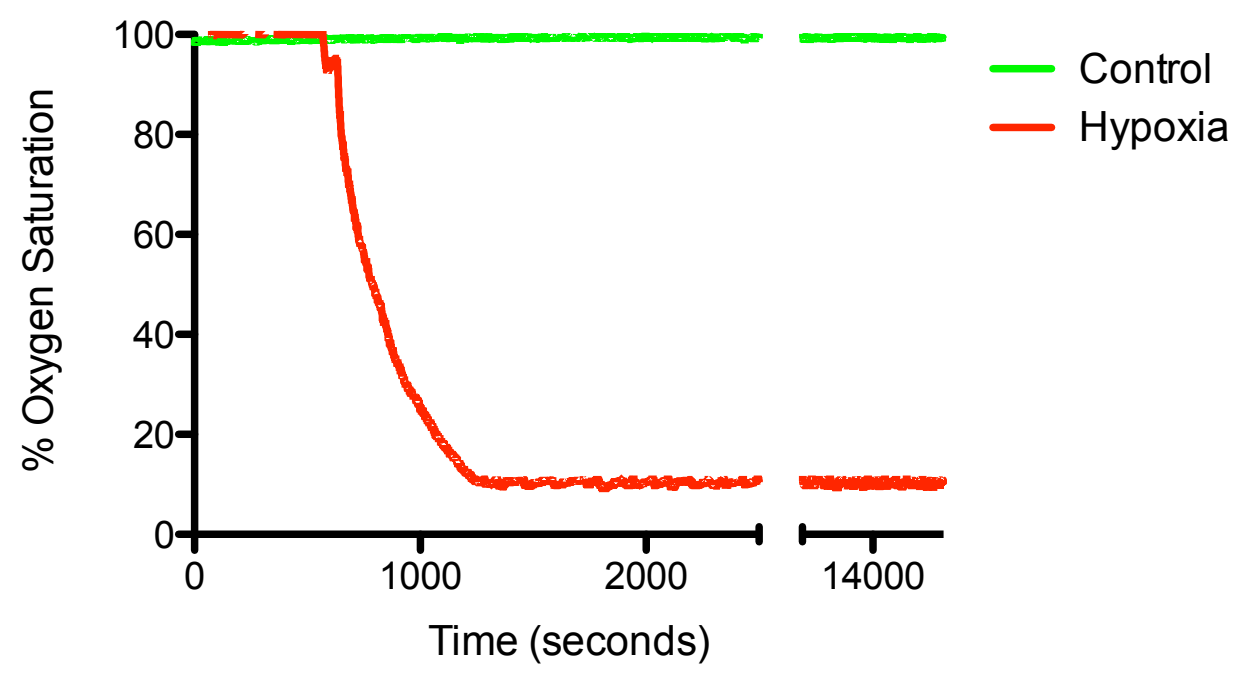

Figures 3 a. Oxygen saturation in control and experimental (hypoxia) tanks throughout the duration of experiment trial one.

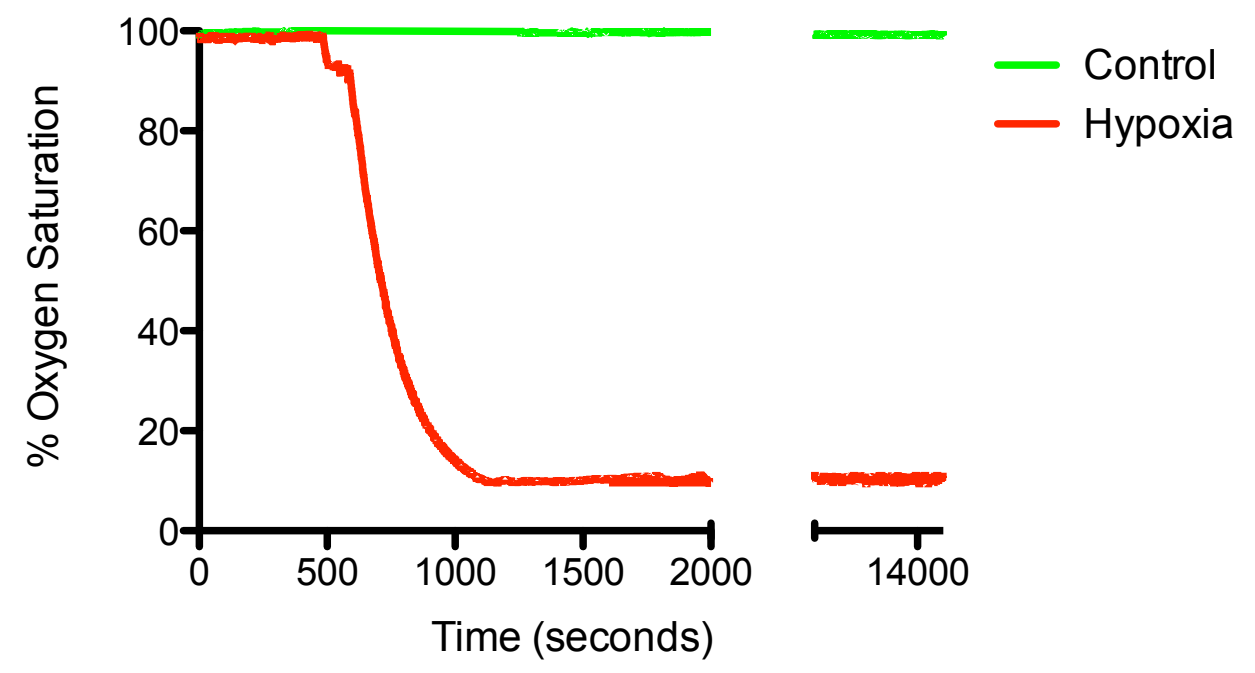

Figures 3 b. Oxygen saturation in control and experimental (hypoxia) tanks throughout the duration of experiment trial two. 


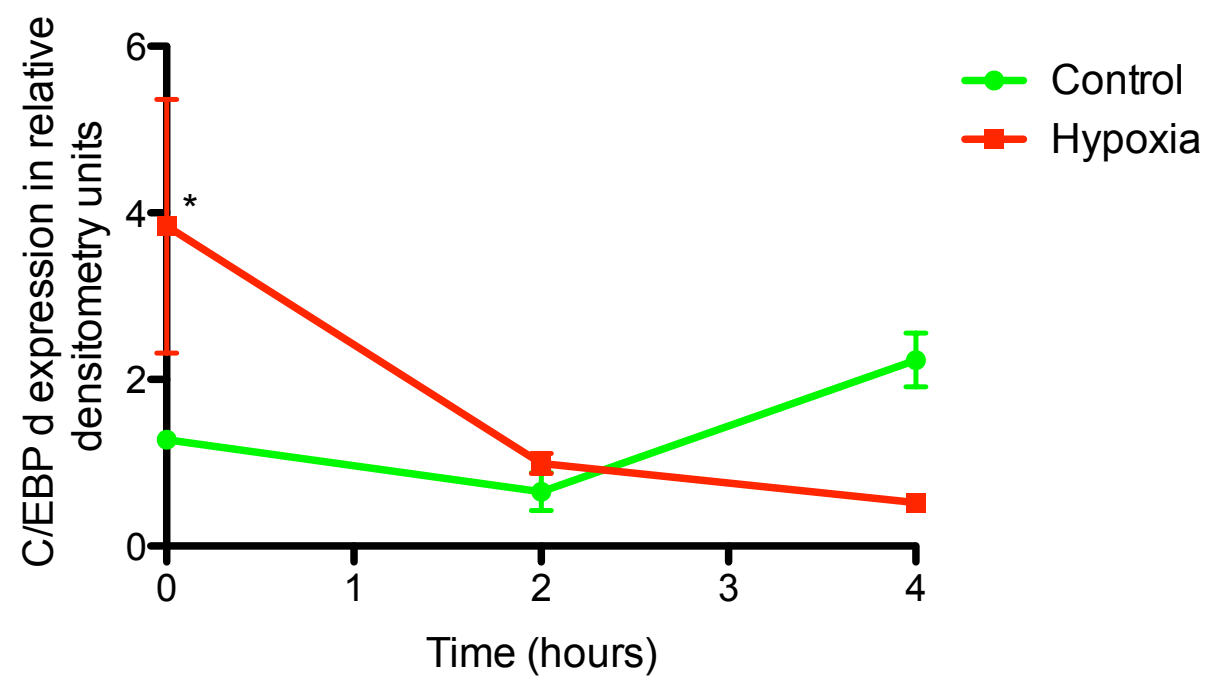

Figure 4. $C / E B P-\delta$ expression in relative densitometry units for control and hypoxia exposed zebrafish white muscle at zero, two and four hour time points from trial one. * indicates that C/EBP- $\delta$ production by fish in the hypoxia tank at the 0 hour time point was greater and significantly different than their control counterparts were at the 0 hour time point. 


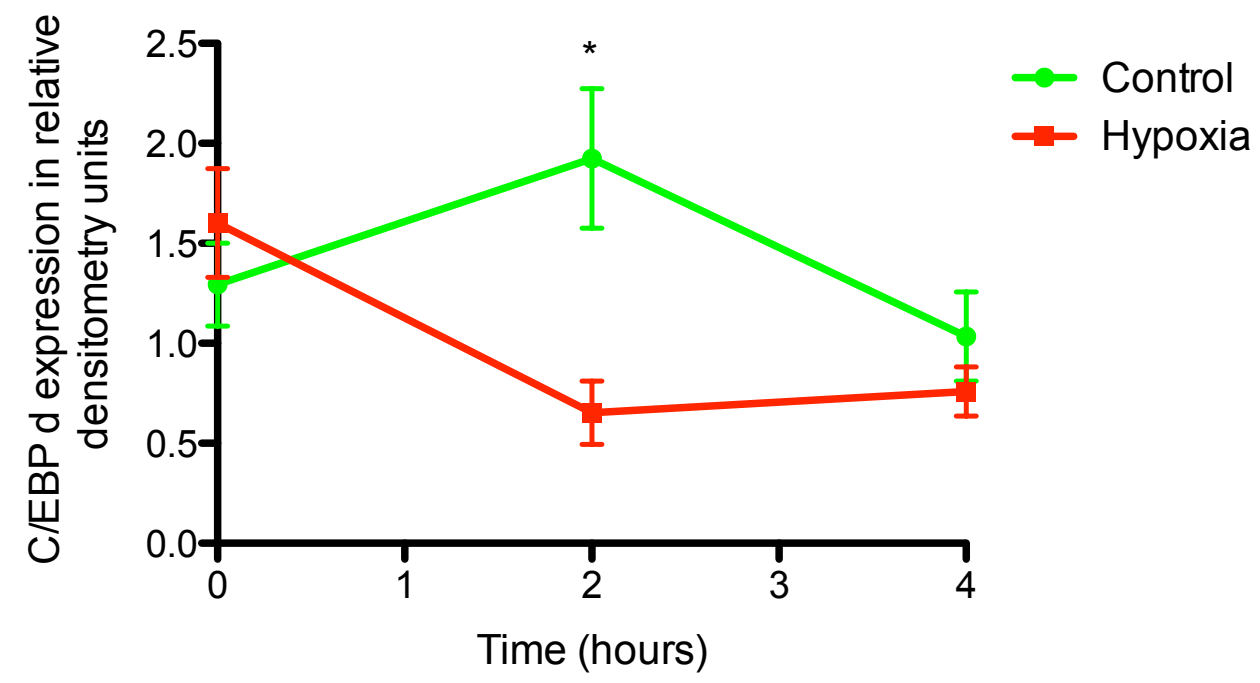

Figure 5. C/EBP- $\delta$ expression in relative densitometry units for control and hypoxia exposed zebrafish white muscle at zero, two and four hour time points from trial two. * indicates that C/EBP- $\delta$ production by fish in the control tank at the 2 hour time point was greater and significantly different than their hypoxiatreated counterparts were at the 2 hour time point. 


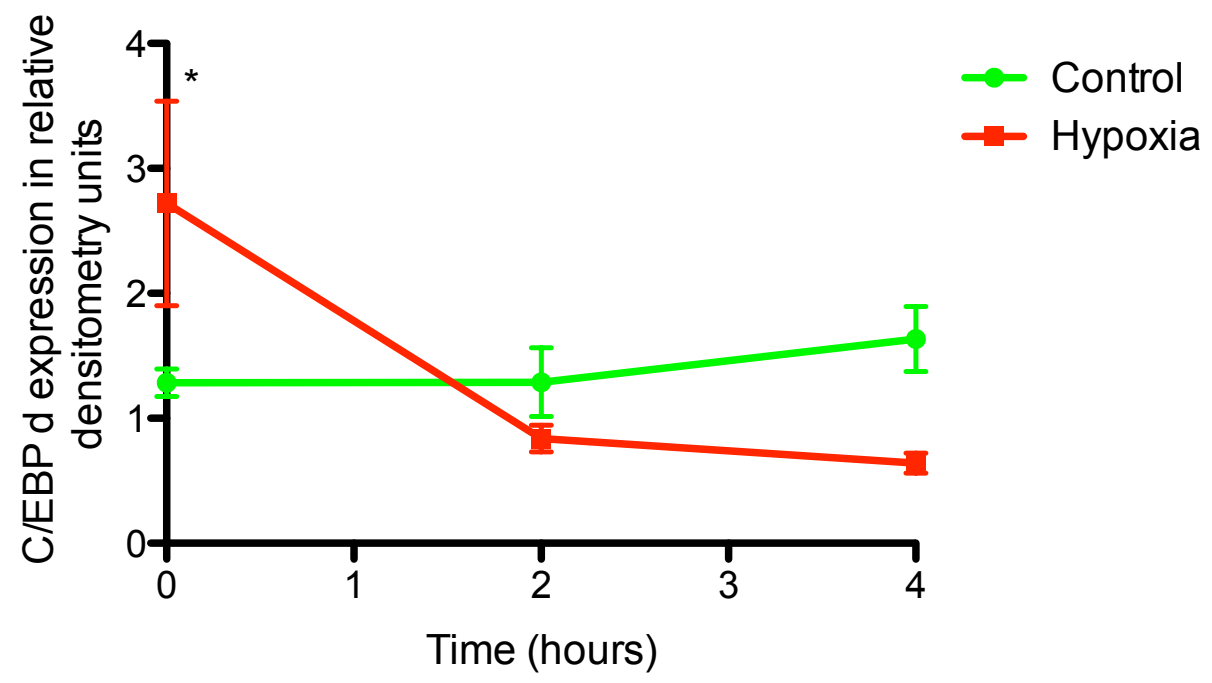

Figure 6. C/EBP- $\delta$ expression in relative densitometry units for control and hypoxia exposed zebrafish white muscle at zero, two and four hour time points after results from trial one and two were pooled. * indicates that $\mathrm{C} / \mathrm{EBP}-\delta$ production by fish in the hypoxia tank at the 0 hour time point was greater and significantly different than their control counterparts were at the 0 hour time point. 


\title{
CHAPTER 3: Gadd45- $\alpha$ expression in heat-shocked liver tissue from an Antarctic notothenioid fish, Trematomus bernacchii.
}

\begin{abstract}
Throughout their millions of years of evolution in the cold, stable Southern Ocean, the Antarctic notothenioid fishes have acquired cold-adapted physiologies. One species, Trematomus bernacchii, has lost the ability to up-regulate the expression of any size class of heat shock proteins (Hsps). However, cDNA microarray analysis has shown that it has retained the ability to modify gene expression in response to heat stress. Many of these genes play pivotal roles in the evolutionarily conserved cellular stress response (CSR). The CSR involves a suite of genes and their respective proteins, which are involved in a wide range of molecular functions and cellular processes, including but limited to molecular chaperoning, cell cycle arrest, metabolic adjustments and in some cases, apoptosis.
\end{abstract}

Here, I examined the growth arrest and DNA damage protein 45- $\alpha$ (gadd45- $\alpha$ ). Gadd45- $\alpha$ genes function as stress sensors involved in the response of cells to physiological stressors and in tumor formation. Gadd45- $\alpha$ proteins interact with stressresponsive proteins including PCNA, p21 and p38 kinase. Liver, gill and whilte muscle tissue from the Antarctic notothenioid species, T. bernacchii were exposed to a range of temperatures and were sampled over a time series, to determine if gadd $45-\alpha$ is heatinducible in thermally stressed Antarctic fishes. When compared across all time points and temperature ranges, gadd45- $\alpha$ expression in isolated liver tissue was significantly different $(\mathrm{p}<0.05)$ in samples exposed to $2^{\circ} \mathrm{C}$, across all time points and was greatest at the 24-hour time point. Gill and white muscle tissue did not cross-react with the 
polyclonal gadd45- $\alpha$ antibody. As this protein can play a role in cell cycle regulation, I postulated that under sub-lethal heat stress, $T$. bernacchii undergoes cell cycle arrest in order to conserve energy for cytoprotective functions. 


\section{Introduction}

The opening of the Drake Passage in the early Cenozoic period lead to the establishment of the Antarctic Circumpolar Current and the subsequent isolation and rapid cooling of the Southern Ocean (Kennett, 1977). During this time, many organisms migrated to warmer climates or went extinct (Hochachka and Somero, 2002). However, some taxa, including the Notothenioid fishes were able to adapt to the near freezing temperatures and have continued to evolve and thrive for the past 14.2 to 13.8 million

years (Eastman, 1993; Eastman and McCune, 2000; Shevenell et al., 2004). Antarctic fish are highly adapted to the harsh environment they live in. As the water temperature stays at $-1.86^{\circ} \mathrm{C}$ for most of the year and only rarely rises above $0^{\circ} \mathrm{C}$ during a brief period of time in the summer (Hunt et al., 2003), the Antarctic Notothenoids have developed some novel adaptations in order to survive in their subzero environment. These adaptations include anti-freeze glycoproteins which bind to early forming ice crystals in their blood and prevent them from propagating (DeVries, 1971), enzymes with higher catalytic efficiencies to function in the extreme cold (Fields and Somero, 1998), cytoskeletal elements capable of polymerization at temperatures below $0^{\circ} \mathrm{C}$ (Detrich et al., 2000) and in some cases, a total loss of reliance on oxygen-carrying hemoproteins in the blood and muscle (Sidell and O’Brien, 2006).

However, while these novel adaptations have allowed these organisms to persist at such low temperatures, the stability of this climate seems to have also lead to a loss of an otherwise highly conserved physiological response, namely, the heat shock response (HSR). The heat shock response is the ability of an organism to up-regulate the production of heat shock proteins in response to elevated temperatures (Hofmann et al., 
2000; Buckley et al., 2004; Buckley and Somero, 2009). Heat shock proteins are instrumental in preventing the aggregation of stress-denatured proteins and also assist (or chaperone) in refolding proteins back into their native state (Hochachka and Somero, 2002). Since an inducible HSR is the most conserved cellular response to heat stress in nearly all taxa (Feder and Hofmann, 1999), its loss in Antarctic fishes raises questions about what other heat-responsive cytoprotective mechanisms may have been modified due to their millions years of evolution in the extremely cold Southern Ocean. Although no heat shock proteins of any size class are heat-inducible, hundreds of other genes from numerous functional classes are responsive to thermal stress at the mRNA level (Buckley and Somero, 2009). This raises the possibility that other genes involved in the CSR remain inducible by sub-lethal heat exposure in these fishes and that in the absence of a heat-inducible HSR, other aspects of the CSR, such as cell cycle arrest or apoptosis may be favored during exposure to sub-lethal heat stress.

The gadd45- $\alpha$ (growth arrest and DNA-damage inducible) gene family is made up of three highly homologous proteins: gadd $45-\alpha$, gadd $45-\beta$, and gadd $45-\gamma$ (Fornace et al, 1988; Abdollahi et al, 1991; and Zhang et al., 1999). Recently, it has been discovered that gadd45 proteins play similar, but not identical roles that regulate important processes such as regulation of DNA repair, negative growth control, cell cycle regulation, and apoptosis (Fornace et al., 1992; Azam et al., 2001; Liebermann and Hoffman, 2002: Vairapandi et al., 2002 and Peretz et al., 2007). Exposure to genotoxic and environmental stressors results in the rapid increase in the concentration of gadd $45-\alpha$ protein, which affect cell cycle regulation through interactions with PCNA (Kelman and Hurwitz, 1998; Azam, 2001), cyclin-dependent kinase inhibitor p21 (Kearsey, 1995) and Cdk/cyclin B 
complex (Zhan, 1999; Jin, 2002; Vairapandi, 2002). Gadd45- $\alpha$ may also play a role in inducing apoptosis (Takekawa; 1998; Harkin, 1999, Zhang et al., 2001). However, this role has not been completely elucidated (Sheikh et al., 2000). While its role in apoptosis is still debated, its role in cell cycle regulation in response to DNA damaging agents or direct DNA damage is well supported. For example, in one study, UV radiation, destabilized nucleosome structure and gadd $45-\alpha$ was up-regulated in response to this destabilization (Carrier et al., 1999). In the same study, gadd45- $\alpha$ was able to recognize damaged chromatin, modify chromatin accessibility, modify DNA accessibility on damaged chromatin, interact with altered mononucleosomes and facilitate topoisomerase activity (Carrier et al., 1999). The role of gadd $45-\alpha$ as a cell cycle regulator is also supported by the finding that gadd $45-\alpha$ proteins can induce G2/M arrest and modulate apoptosis in kidney cells exposed to hyperosmotic stress (Mak and Kültz, 2004).

The effect of heat stress on gadd45- $\alpha$ regulation has been relatively unexplored. As heat stress is known to cause damage to DNA (Banks et al., 2005), DNA repair mechanisms should be up-regulated in response to stressful levels of heat in order to alleviate this damage. If left unrepaired, damaged DNA will be passed onto daughter cells which can lead to deleterious effects such as uncontrolled cell division in the case of damage to the p53 gene (Liu and Kulesz-Martin, 2001). Due to its multiple roles in recognizing damaged DNA, facilitating DNA repair (Carrier et al., 1999) and halting the cell cycle (Mak and Kültz, 2004) to conserve energy for these processes, I hypothesized that gadd45- $\alpha$ would be responsive to non-lethal heat stress. Here, I investigated the temperature-responsiveness of this gene by measuring gadd $45-\alpha$ protein levels in isolated liver, gill and white muscle tissue of cold-adapted Antarctic fish, Trematomus bernacchii 
under physiological conditions as well as during acute and chronic heat stress. 


\section{Materials and methods}

Animal collection

The emerald rockcod, Trematomus bernacchii (Figure 7), is a benthic fish that is one of the most common species in Erebus bay of McMurdo sound at $78^{\circ}$ South latitude (Gon and Heemstra, 1990), where the water temperature is consistently near $-1.86^{\circ} \mathrm{C}$ with rare fluctuations to near $0^{\circ} \mathrm{C}$ (Hunt et al., 2003). T. bernacchii can acclimate to $4^{\circ} \mathrm{C}$ but their upper lethal temperature limit is $6^{\circ} \mathrm{C}$ (Somero and DeVries, 1967). Specimens of T. bernacchii were caught by hook-and-line in October and November 2011 in the nearshore waters of McMurdo Sound, Antarctica at three sites: Inaccessible Island, the Cape Evans Wall and the jetty near McMurdo Station (Figure 8). Fish were collected from depth ranges of 18-30 meters. Fish were transported to McMurdo Station in coolers and maintained in running seawater aquaria in the Crary laboratory. Fish were allowed to acclimate to tank conditions for at least 48 hours before being used in experiments. Fish were not fed for 48 hours before being used in experiments.

\section{Heat shock treatment}

Five individuals were anesthetized via immersion in MS-222 (at a concentration of $1 \mathrm{~g} / \mathrm{L} \mathrm{L}$ in seawater). The hepatic portal vein was cannulated and the livers perfused with a buffer containing $290 \mathrm{mmol} \mathrm{NaCl}, 2 \mathrm{mmol} \mathrm{KCl}, 10 \mathrm{mmol}$ Hepes, $0.5 \mathrm{mmol}$ EGTA and 25 mmol Tricine ( $\mathrm{pH} 7.4$ ), to remove red blood cells. Once perfused, liver, gill and white muscle tissues were sectioned into 21 equally sized sections. One section of each tissue was immediately flash frozen in liquid nitrogen. The remaining 20 sections were placed into labeled microfuge tubes containing $0.5 \mathrm{~mL}$ Notothenoid Ringers solutions (311 mmol NaCl, 5 mmol KCl, 2.5 mmol $\mathrm{MgCl}_{2}, 3$ mmol Ca Cl $2,2.5$ mmol $\mathrm{NaHCO}_{3}, 2$ mmol 
$\mathrm{NaH}_{2} \mathrm{PO}_{4}$ and $5 \mathrm{mmol}$ glucose ( $\mathrm{pH}$ 7.4). Five sections of each tissue were placed into water baths held at constant temperatures of $-2^{\circ}, 2^{\circ}, 6^{\circ}$ or $10^{\circ} \mathrm{C}$. One sample of each liver, gill and white muscle tissue was removed from each water bath at time points of 2 , 4, 8, 12 and 24 hours and flash frozen in liquid nitrogen.

\section{Tissue preparation}

Liver, gill, and white muscle were homogenized in lysis buffer containing $10 \%$ sodium dodecyl sulfate (SDS), and $0.032 \mathrm{~mol}$ TRIS. Samples were incubated at $100^{\circ} \mathrm{C}$ for five minutes, and centrifuged at $13,500 \times \mathrm{g}$ for 20 minutes to remove cellular debris. Protein content of the $13,500 \times \mathrm{g}$ supernatants was determined using a modified Bradford assay and samples were stored at $-80^{\circ} \mathrm{C}$ until use.

Polyacrylamide gel electrophoresis (PAGE)

Prepared samples were electrophoresed on $8.3 \mathrm{~cm} \times 7.5 \mathrm{~cm}, 0.75 \mathrm{~mm}, 10 \%$ SDSTris-glycine polyacrylamide gels. Each lane of the gel was loaded with a sample with a protein concentration of $15 \mu \mathrm{g} / \mu \mathrm{L}$ and a lysis buffer volume to total $10 \mu \mathrm{L} .10 \mu \mathrm{l}$ of $2 \times$ SDS-PAGE sample buffer was added to each sample. Finally all samples were heated for 3 minutes at $100^{\circ} \mathrm{C}$ and each entire sample was electrophoresed at $130 \mathrm{~V}$ for 1.5 hours.

\section{Protein concentration determination via immunoblotting (western blotting)}

Nitrocellulose membranes $(0.2 \mu \mathrm{m}, \mathrm{BIO}-\mathrm{RAD})$ were soaked in nano-water for 30 minutes, one hour prior to transfer assembly. Transfer was conducted overnight at $30 \mathrm{~V}$. Following transfer, membranes were blocked for one hour in 5\% non-fat milk dissolved in $1 \times$ Phosphate Buffered Saline (PBS) with gentle agitation. Following blocking, membranes were incubated in a 1:500 dilution of gadd45- $\alpha$ polyclonal antibody (Santa Cruz Biotechnologies) diluted in $40 \mathrm{~mL}$ of milk block for 1.5 hours at room temperature. 
Following incubation, membranes were washed three times for 10 minutes per wash in a $1 \times$ PBS $+0.1 \%$ TWEEN solution. Next, membranes were incubated in a 1:2,500 dilution of a goat-anti-rabbit polyclonal antibody diluted in $40 \mathrm{~mL}$ of milk block for one hour at room temperature. Membranes were washed six times for five minutes per wash in $1 \mathrm{x}$ PBS $+0.1 \%$ TWEEN. Membranes were soaked in four $\mathrm{mL}$ of Chemiluminescent solution (Thermo Scientific Super Signal West Pico Chemiluminescent Substrate) for five minutes. Membranes were then wrapped in plastic wrap and placed in developing cassette (Four Square). The membranes were exposed to x-ray film (Thermo Scientific CL-X Posure Film). Band intensity from individual blots was measured by ImageJ. Band size and intensities of samples were compared to an internal standard that was loaded onto each gel. For a list of all tissues and antibodies tested, see Appendix.

\section{Statistics}

All temperatures and time points were analyzed using one-way ANOVA between temperatures. Differences between values at a given time point were determined via posthoc Bonferroni correction using GraphPad Prism software. 


\section{Results}

Gadd45- $\alpha$ concentrations in isolated liver tissue from individuals exposed to $2^{\circ} \mathrm{C}$ were significantly different from control values at all time points $(\mathrm{df}=3 ; \mathrm{P}<0.05)$ and were greatest at the 24-hour time point (Figure 9). No significant difference in gadd45- $\alpha$ levels vs. control values was found for any other temperatures. The commercial antibody I employed did not cross-react with gadd45- $\alpha$ in the gill or white muscle tissue of $T$. bernacchii, so here I report only the results from the liver samples. 


\section{Conclusion}

In this study, I measured how gadd45- $\alpha$ levels varied in response to lethal and sublethal heat stress in isolated liver tissue from a common species of Antarctic fish, $T$. bernacchii. The Antarctic notothenioid fishes found in the cold and stable waters of McMurdo Sound rarely see temperature fluctuations above $0^{\circ} \mathrm{C}$ (Hunt, 2003). $T$. bernacchii is able to acclimate to temperatures as high as $4^{\circ} \mathrm{C}$, however, the upper lethal limit is $6-8^{\circ} \mathrm{C}$ (Somero and Hochachka, 1969). It has been proposed that acetylcholine cannot function properly at temperatures of $6^{\circ} \mathrm{C}$ and higher in Antarctic nothothenioids (Hochachka and Somero, 2002). Yet individual cells and tissues may be able to continue function at temperatures higher than the upper lethal limit of a whole organism. For this reason, I chose to expose the tissues to $-2^{\circ} \mathrm{C}$ as a control and $2^{\circ} \mathrm{C}$ as a temperature that the organisms may be able to still respond. The $6^{\circ} \mathrm{C}$ and $10^{\circ} \mathrm{C}$ were chosen as upper limit controls as these are not temperatures in which the whole organism would be able to function.

My data show that $T$. bernacchii is able to up-regulate gadd45- $\alpha$ expression in response to heat shock. T. bernacchii was able to increase protein concentrations of gadd $45-\alpha$ during exposure to $2^{\circ} \mathrm{C}$, with the highest amount of gadd45- $\alpha$ being measured at the 24-h time point. These findings are consistent with the idea that $T$. bernacchii liver tissue responds to heat shock by halting the cell cycle, a concept also supported by the fact that another cell cycle regulator, $\mathrm{C} / \mathrm{EBP}-\delta$ is also up-regulated in response to heat shock in this species (Sleadd and Buckley, in press). It is possible that temporarily exiting the cell cycle during stress could be adaptive for at least two reasons. First, during heat stress, cells may be incurring DNA damage. Before the cells replicate, this damage must 
be repaired. As gadd45- $\alpha$ is involved in not only recognizing DNA damage, but also is involved in initiating DNA repair mechanisms (Carrier et al., 1999), it is highly likely that the cell cycle is being stopped in order to repair damaged DNA. Second, inhibition of the cell cycle may be happening to preserve energy for other cytoprotective mechanisms as well. This is in keeping with evidence that metabolic adjustments are an important part of the CSR. As Antarctic fishes are metabolically depressed compared to their temperate and tropical counterparts, initiating energy-saving mechanisms during bouts of stress may be of critical importance.

While it is interesting to note that only at $2{ }^{\circ} \mathrm{C}$ was gadd $45-\alpha$ up-regulated in a statistically significant manner, the data show a pattern that is quite common in other studies of heat stress and thermal tolerance. At $-2^{\circ} \mathrm{C}$, protein production was low, at $2^{\circ} \mathrm{C}$, protein production was at its highest, began to fall off at $6^{\circ} \mathrm{C}$ and was quite low again at $10^{\circ} \mathrm{C}$. This pattern of changes in protein synthesis in response to thermal changes is not novel in itself. In fact, the pattern follows a strict thermodynamic pattern that has been demonstrated many times over. For example, Tomanek and Somero (1999) used four congeners of marine snails from the genus Tegula to determine at which temperature heat shock protein (Hsp) synthesis was first initiated $\left(\mathrm{T}_{\text {on }}\right)$, which temperature Hsps were produced at their maximum $\left(\mathrm{T}_{\text {peak }}\right)$, and which temperature Hsps were heat inactivated $T_{\text {off). }}$. The $T_{\text {on }}, T_{\text {peak }}$ and $T_{\text {off }}$ temperatures for the four different congeners of snail species were different, however the pattern that they showed was similar. All showed that at temperatures higher than they normally experienced, more proteins were produced but as temperatures became too hot, protein production fell off rapidly (Tomanek and Somero, 1999). This pattern has also been shown in many other organisms as well including the 
intertidal muscles Mytilus trossulus and Mytilus galloprovincialis (Hofmann and Somero, 1996), limpets of the genus Collisella (Sanders et al., 1991), and a heat- adapted ant (genus Cataglyphis) from the Sahara compared with a temperate living ant (genus Formica) (Gehring and Wehner, 1995). Therefore, this pattern of a rise and then fall of protein synthesis in response to rising temperatures is not surprising. What is surprising is how far the temperatures have been shifted on the scale. The intertidal muscles in the genus Mytilus have live in temperatures ranging between $12-33^{\circ} \mathrm{C}$, a thermotolerance range of $21^{\circ} \mathrm{C}$ while the upper lethal limit for T. bernacchii is only $6^{\circ} \mathrm{C}$ (Somero and DeVries, 1967) giving them a thermotolerance range of less than $8^{\circ} \mathrm{C}$ (between $-1.86^{\circ} \mathrm{C}$ and $6^{\circ} \mathrm{C}$ ). It is interesting to note that while both C/EBP- $\delta$ (Sleadd and Buckley, in press) and gadd45- $\alpha$ are up-regulated in response to heat stress in T. bernacchii, Hsps are not (Buckley et al., 2004).

More research is needed into the mechanisms that underlie thermal tolerance in the stenothermal fishes of Antarctica and the physiological stress responses available to species. While we have gained a quite a bit of knowledge over the last several years regarding how Antarctic fishes respond to sub-lethal heat stress at the cellular level, no research has been done on long term acclimation, reproduction and development at sublethal heat stresses. Future studies should be multi-faceted and involve both whole organism and cellular studies. Whole organisms studies should involve keeping adult fish at $-2^{\circ} \mathrm{C}, 0^{\circ} \mathrm{C}, 2^{\circ} \mathrm{C}$ or $4^{\circ} \mathrm{C}$ for long-term growth evaluations. Also, It would be interesting to raise Antarctic fishes from embryos at $-2^{\circ} \mathrm{C}, 0^{\circ} \mathrm{C}, 2^{\circ} \mathrm{C}$ or $4^{\circ} \mathrm{C}$ examine differences in development, growth rate, time to reproductive maturity, number of eggs laid, and number of individuals that survive to adulthood. For a cellular approach, isolated 
hepatocytes (see Buckley et al., 2004) could be exposed to the same temperatures and time points as isolated tissues were in this gadd $45-\alpha$ study to study direct measures of cell cycle arrest using flow cytometry. We know that both C/EBP- $\delta$ (Sleadd and Buckley, in press) and gadd45- $\alpha$ are up-regulated in response to non-lethal heat stress, but we do not know where in the cell cycle these cells are being arrested or if they are entering apoptosis. Information from these studies will help us better understand how stressful different temperatures really are. Gaining a better understanding of these mechanisms in response to sub-lethal heat stress will be critical as we continue to monitor the effects of rising ocean temperatures on the biology and ecology of these environmentally sensitive species. 


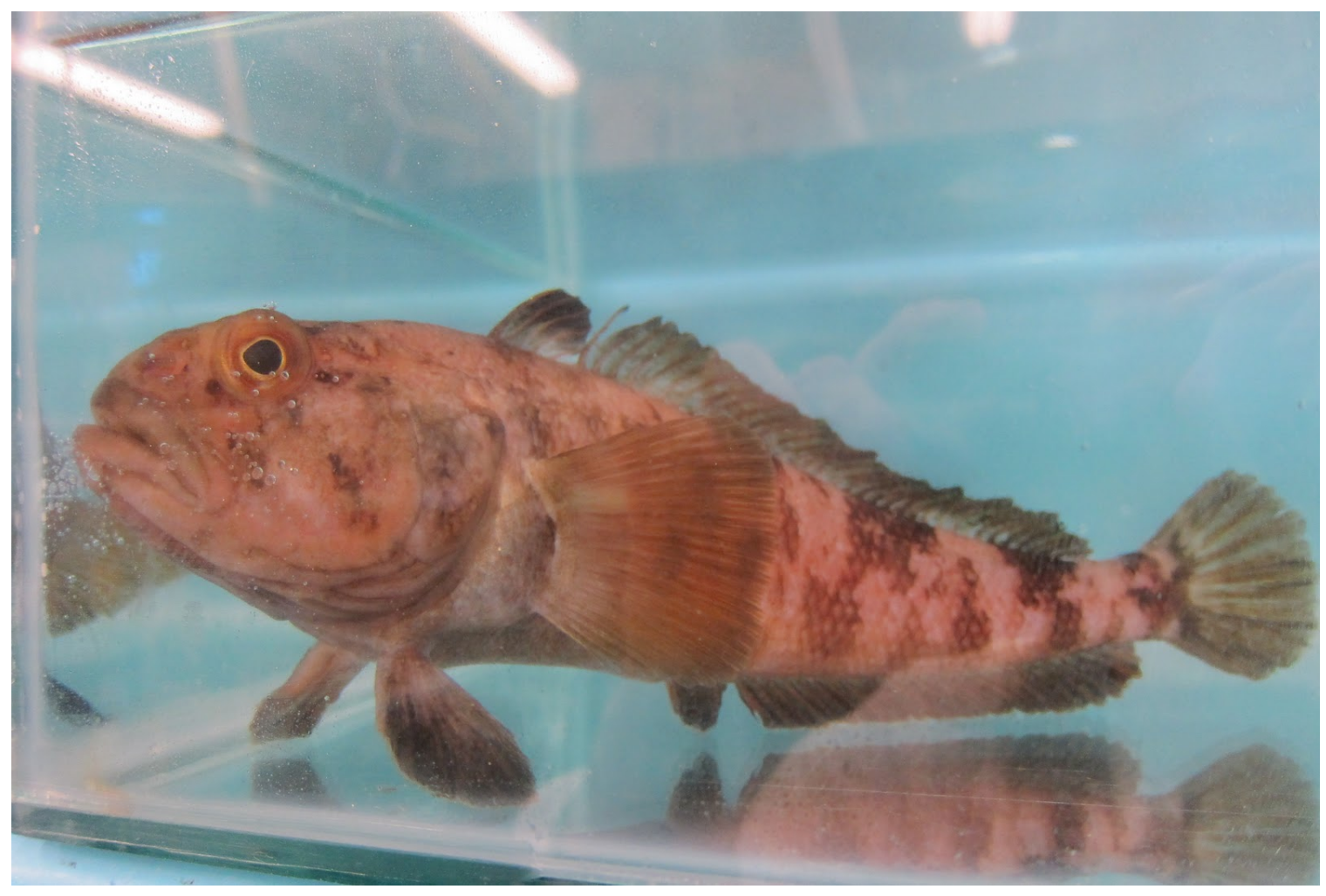

Figure 7. The Antarctic emerald rockcod, Trematomus bernacchii. (photo courtesy of A. Barden). 


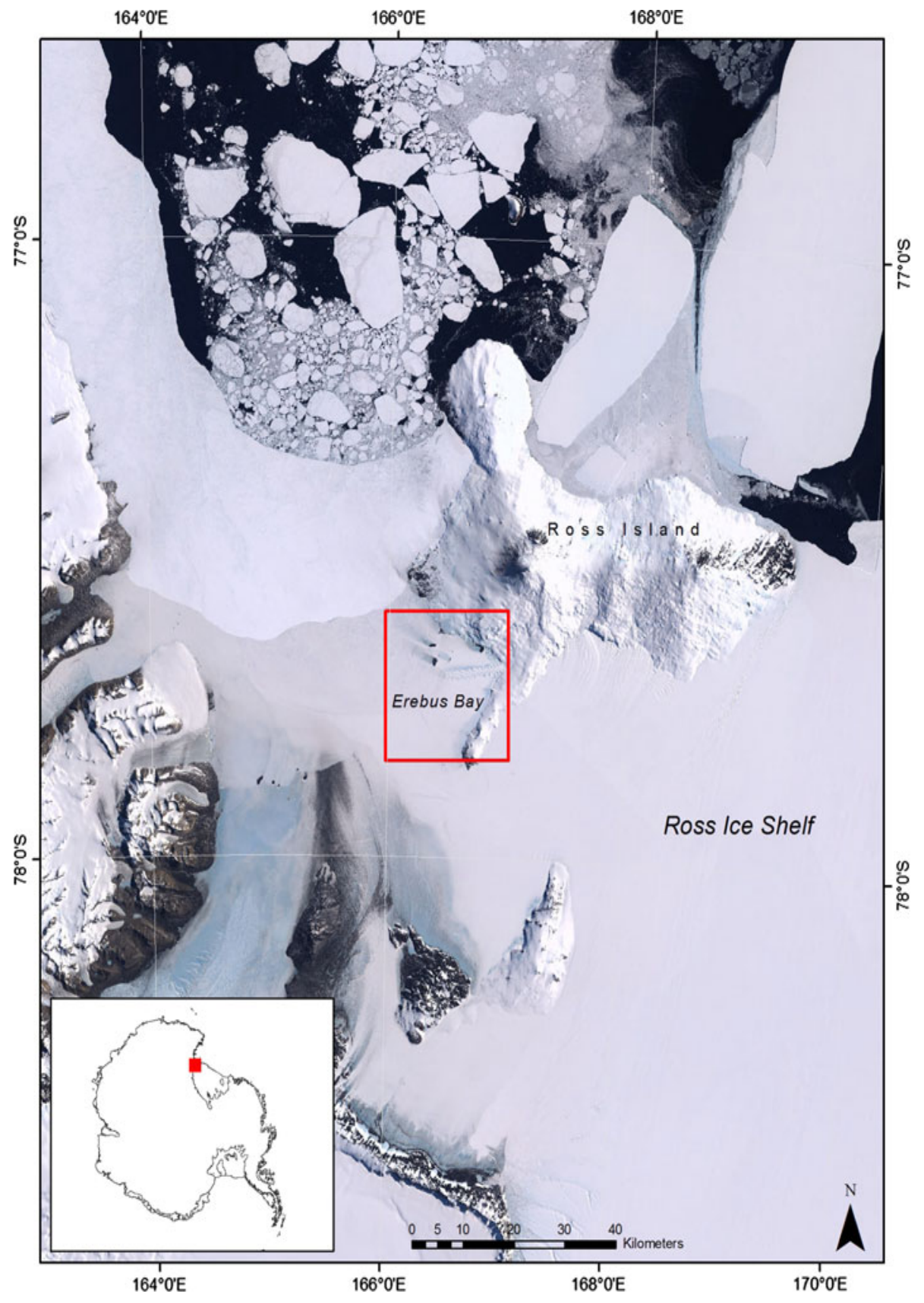

Figure 8. Ross Island in McMurdo Sound Antarctica. Red box denotes Erebus Bay, location of the three samples sites for the study (Map courtesy of M. LaRue of the Polar Geospatial Center). 


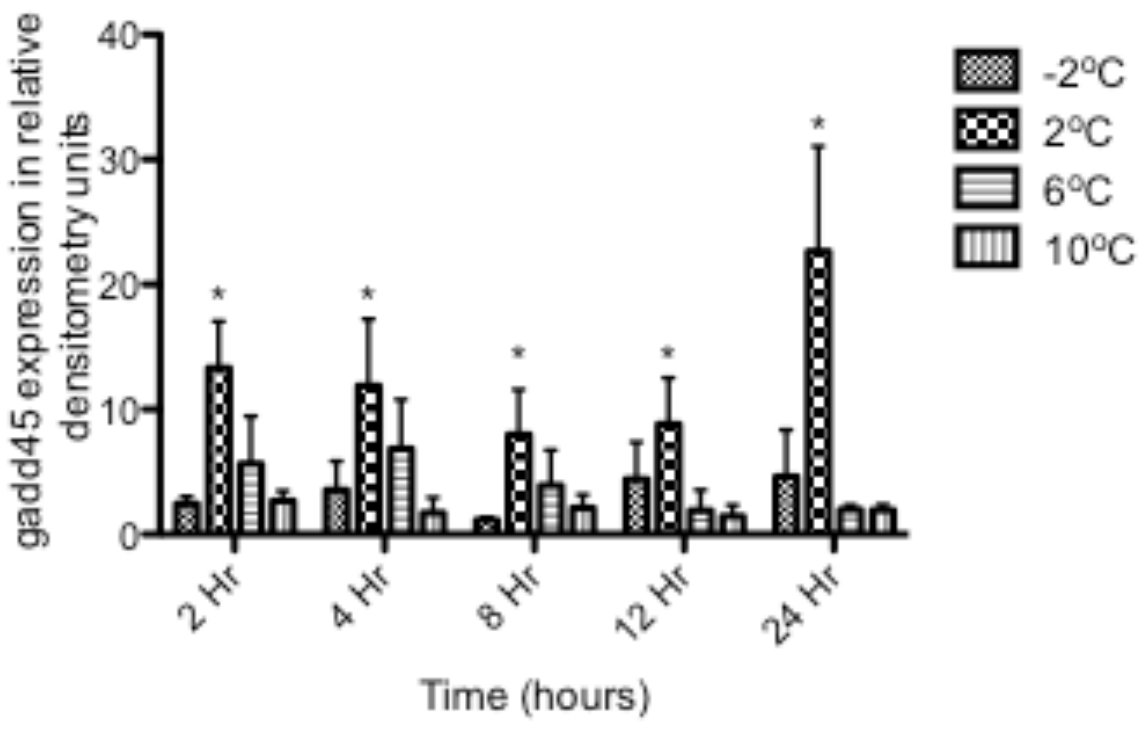

Figure 9. Gadd45- $\alpha$ expression in isolated liver tissue from Trematomus bernacchii that was exposed to either $2^{\circ}, 2^{\circ}, 6^{\circ}$ or $10^{\circ} \mathrm{C}$ for a range of durations. Results from one-way ANOVA with post hoc Bonferroni multiple comparison tests. $*$ indicate statistically significant differences within a time point and between temperature treatments. For all time points, only $2^{\circ}$ was able to significantly up-regulate gadd $45-\alpha$. 


\section{CHAPTER 4: Conclusions}

The CSR is an integrated set of mechanisms that function as an adaptive way to protect cells from environmental stress, thereby allowing those cells to conserve energy by halting the cell cycle, repair damaged macromolecules and DNA, and provide other cytoprotective measures for the cells (Kültz, 2005). These processes are tightly regulated by transcription factors, which are rapidly up-regulated in response to stressors, and upon return to non-stressful conditions, rapidly down-regulated. In doing so, this allows those cells (and the entire organism) to survive bouts of temporary stressful conditions and return to homeostatic conditions relatively quickly once those stressors have passed. It is the significance of one aspect of the CSR, cell cycle regulation, that has attracted much attention by those in cancer research (Kültz, 2005). Exploring the mechanisms by which these "molecular stop signs", or cell cycle checkpoints, function is a quickly developing field and will have major implications in the future of cancer research as well as the study of the CSR in general.

The cell cycle regulatory role of these genes and proteins has major implications beyond just cancer research. Exploring the most highly conserved mechanisms of the CSR help us better understand evolution as well. C/EBP- $\delta$ is a highly conserved transcription factor and major role player of the CSR, being the only gene that was upregulated in response to heat shock among heat stressed T. bernacchii (Buckley and Somero, 2008), Gillichthys mirabilis (Buckley et al., 2006), the bluefin tuna (Thunnus orientalis) (Castilho et al., 2009) and the zebrafish (Danio rerio) (Buckley, unpublished data). My study on C/EBP- $\delta$ in zebrafish showed that C/EBP- $\delta$ is not up-regulated in response to hypoxia as I originally hypothesized. This was surprising as many other 
aspects of the CSR including Hsps, gadd45- $\alpha$ and HIF-1 $\alpha$ respond to different environmental stressors (such as heat shock and hypoxia) in a similar pattern. As described above, there are several potential reasons that my hypothesis was not correct and more research will be needed to determine if C/EBP- $\delta$ is truly not responsive to hypoxia in zebrafish.

As I was interested in investigating aspects of the CSR that are involved in cell cycle regulation, I also examined gadd $45-\alpha$, a well-researched family of proteins that are responsive to both genotoxic and non-genotoxic stresses. While its role as a cell cycle regulator has been studied in response to UV irradiation (Carrier et al., 1999) and hyperosmotic stress (Mak and Kültz, 2004), its role in heat stress had yet to be explored before this study. My results showed that gadd45- $\alpha$ is up-regulated in response to heat shock in the cold-adapted stenothermal fish $T$. bernacchii, but interestingly, that it was only up-regulated during sub-lethal heat stress $\left(2^{\circ} \mathrm{C}\right)$. This finding suggests that its upregulation is adaptive rather than the response of a dying cell. These results were novel for two reasons; the first being that it is the first time that gadd45- $\alpha$ has been studied in $T$. bernacchii and the second being it is one of the first to explore if gadd45- $\alpha$ proteins are up-regulated in response to thermal stress in any organism. Continuing to elucidate the mechanisms by which gadd $45-\alpha$ functions is important because, like C/EBP- $\delta$, gadd $45-\alpha$ is tightly involved in cell cycle regulatory pathways. A better characterization of how these pathways function is important for continuing to fully understand the CSR in its entirety.

While only two aspects of the CSR were explored in this thesis, there are many future directions that these studies could lead to. For example, since gadd45- $\alpha$ was shown 
to be up-regulated during heat stress in T. bernacchii, it would be interesting to see if it is also up-regulated in zebrafish in response to hypoxia. Also, other proteotoxic stressors such as exposure to $\mathrm{CdCl} 2$ and $\mathrm{Mg} 132$ could be examined on T. bernacchii to determine if gadd45- $\alpha$ responds to all proteotoxic stressors in a similar pattern. Also, while C/EBP- $\delta$ was not shown to be up-regulated during hypoxia in zebrafish, future studies could include longer exposure times, lower $\mathrm{O}_{2}$ saturation, and multi-tissue analysis. It would also be interesting to do mRNA and ubiquitin studies to determine if during hypoxia, more $\mathrm{C} / \mathrm{EBP}-\delta$ is being produced but is also being degraded quickly as well. Finally, while overall $\mathrm{C} / \mathrm{EBP}-\delta$ concentration did not change, this is not to say that $\mathrm{C} / \mathrm{EBP}-\delta$ localization was not affected by hypoxia. $\mathrm{C} / \mathrm{EBP}-\delta$ tagging could be used to see if during hypoxia, $\mathrm{C} / \mathrm{EBP}-\delta$ translocates from the cytoplasm into the nucleus. TUNEL staining and flow cytometry studies could also be done to determine cell fate during hypoxia in conjuction with translocation studies to gain a better understanding of C/EBP- $\delta$ function and response to hypoxia.

It is my hope that the results from my studies not only answered some questions, but also lead to many more. I hope that they will lead others to explore future directions and research regarding the CSR and cell cycle regulation. As our knowledge continues to grow on these subjects, I hope that the continued use of model and non-model species will help influence conservation guidelines, studies on global warming, and further developments in cancer research biology as well. 


\section{References}

Abdollahi, A., Lord, K.A., Hoffman-Liebermann, B., and Liebermann, D.A. 1991. Sequence and expression of a cDNA encoding MyD118: a novel myeloid differentiation primary response gene induced by multiple cytokines. Oncogene, 6 (1): $165-7$.

Azam, N., Vairapandi, M., Zhang, W., Hoffman, B., and Liebermann, D. A. 2001. Interaction of CR6 (GADD45) with proliferating cell nuclear antigen impedes negative growth control. Journal of Biological Chemistry, 276: 2766-2774.

Banks, S., King, S. A., Irvine, D. S., and Saunders, P. T. K. 2005. Impact of a mild scrotal heat stress on DNA integrity in murine spermatozoa. Reproduction, 129: $505-514$.

Briggs, J.P. 2002. The zebrafish: a new model organism for integrative physiology. American Journal of Physiology: Regulatory, Integrative and Comparative Physiology, 282: 3-9.

Brown, J. M. 2000. Exploiting the hypoxic cancer cell: mechanisms and therapeutic strategies. Molecular Medicine Today, 6:157-162.

Bosworth IV, C.A., Chou, C., Cole, R.B. and Rees, B.B. 2004. Protein expression patterns in zebrafish skeletal muscle: initial characterization and the effects of hypoxic exposure. Proteomics, 5: 1362-1371.

Buckley, B.A., Gracey, A.Y., and Somero, G.N. 2006. The cellular response to heat stress in the goby Gillichthys mirabilis: a cDNA microarray and protein-level analysis. Journal of Experimental Biology, 209: 2660-2677.

Buckley, B.A., and Hofmann, G.E. 2002. Thermal acclimation changes DNA-binding 
activity of heat shock factor 1 (HSF1) in the goby Gillichthys mirabilis:

implications for plasticity in the heat- shock response in natural populations.

Journal of Experimental Biology, 205: 3231-3240.

Buckley, B.A., and Hofmann, G.E. 2004. Magnitude and Duration of Thermal Stress

Determine Kinetics of hsp Gene Regulation in the Goby Gillichthys mirabilis. Physiological and Biochemical Zoology, 77(4): 570-581.

Buckley, B.A., Owen, M., and Hofmann, G.E. 2001. Adjusting the thermostat: the threshold induction temperature for the heat- shock response in intertidal mussels (genus Mytilus) changes as a function of thermal history. Journal of Experimental Biology, 204: 3571-3579.

Buckley, B.A., Place, S.P., and Hofmann, G.E. 2004. Regulation of heat shock genes in isolated hepatocytes from an Antarctic fish, Trematomus bernacchii. Journal of Experimental Biology, 207: 3649-3656.

Buckley, B.A., and Somero, G.N. 2009. cDNA microarray analysis reveals the capacity of the cold-adapted Antarctic fish Trematomus bernacchii to alter gene expression in response to heat stress. Polar Biology, 32: 403-415.

Bunn, H.F., Gu, J., and Huang, L.E. 1988. Erythropoietin: a model system for studying oxygen dependent gene regulation. Journal of Experimental Biology, 201: 11971201.

Cantwell, C. A, Sterneck, E., Johnson, P. F. 1998. Interleukin-6-specific activation of the C/EBP-d gene in hepatocytes is mediated by Stat3 and Sp1. Molecular Cellular Biology, 18:2108-2117

Cao, Z., Jensen, L. D., Rouhi, P., Hosaka, K., Länne, T., Steffensen, J. F., Erik Wahlberg, 
E., and Cao, Y. 2010. Hypoxia-induced retinopathy model in adult zebrafish. Nature Protocols, 5: 1903-1910.

Carrier, F., Georgel, P., Pourquier, P., Blake, M., Kontny, H.U., Antinore, M.J., Gariboldi, M., Myers, T.G., Weinstein, J.N., Pommier, Y. and Fornace, A.J. Jr. 1999. Gadd45, a p53-responsive stress protein, modifies DNA accessibility on damaged chromatin. Molecular and Cellular Biology, 19: 1673-1685.

Castilho, P.C., Buckley, B.A., Somero, G.N., and Block, B.A. 2009. Heterologous hybridization to a complementary DNA microarray reveals the effect of thermal acclimation in the endothermic bluefin tuna (Thunnus orientalis). Molecular Ecology, 18: 2092-2102.

Chippindale, A., Gibbs, A., Sheik, M., Yee, K., Djawdan, M., Bradley, T., and Rose, M. 1998. Resource acquisition and the evolution of stress resistance in Drosophila melanogaster. Evolution, 52(5): 1342-1352.

Clarkson, R. W. E., Boland, M. P., Kritikou, E. A., Lee, J. M., Freeman, T.C., Tiffen, P.G., and Watson, C. J. 2006. The genes induced by signal transducer and activators of transcription (STAT) 3 and STAT5 in mammary epithelial cells define the roles of these STATs in mammary development. Molecular Endocrinology, 20(3): 675-685.

Dahm, R. 2006. The Zebrafish Exposed. American Scientist. 94 (5): 446-53.

Delaney, M.A., and Klesius, P.H. 2004. Hypoxic conditions induce Hsp70 production in blood, brain and head kidney of juvenile Nile Tilapia, Orechromis niloticus (L.). Aquaculture, 236: 633-644.

Detrich, H.W., Parker, S.K., Williams, R.C., Nogales, E., Downing, K.H. 2000. Cold 
adaptation of microtubule assembly and dynamics: structural interpretation of primary sequence changes present in the a- and b- tubulins of Antarctic fishes. Journal of Biological Chemistry, 275: 37038-37047.

DeVries, A. 1971. Glycoproteins as biological antifreeze agents in Antarctic fishes. Science, 172: 1152-1155.

Dikmen, Z.G., Gellert, G.C., Dogan, P., Yoon, H., Lee, Y.B., Ahn, C.H., and Shay, J.W. 2008. In Vivo and In Vitro Effects of a HIF-1a Inhibitor, RX-0047. Journal of Cellular Biochemistry, 104: 985-994.

Eastman, J.T. 1993. Antarctic Fish Biology: Evolution in a Unique Environment. New York: Academic Press.

Eastman, J.T., and McCune, A.R. 2000. Fishes on the Antarctic continental shelf: evolution of a marine species flock? Journal of Fish Biology, 57: 84-102.

Feder, M.E., and Hofmann, G.E. 1999. Heat-shock proteins, molecular chaperones and the stress response: evolutionary and ecological physiology. Annual Review of Physiology, 61: 243-282.

Ferriero, D.M., Soberano, H.Q., Simon, R.P., and Sharp, F.R. 1990. Hypoxia ischemia induces heat shock protein-like (HSP72) immunoreactivity in neonatal rat brain. Developmental Brain Research, 53: 145-150.

Fields, P.A., and Somero, G.N. 1998. Hot spots in cold adaptation: localized increases in conformational flexibility in lactate dehydrogenase A4 orthologs of Antarctic notothenioid fishes. Proceedings of the National Academy of Sciences, 95: $11476-11481$.

Fink, A.L. 1999. Chaperone-mediated protein folding. Physiology Review, 79: 425-449. 
Fornace, A.J., Alamo, I., and Hollander, M.C. 1988. DNA damage-inducible transcripts in mammalian cells. Proceedings of the National Academy of Sciences, 85 (23): $8800-4$.

Fornace, A.J., Jackman, J., Hollander, M.C., Hoffman-Liebermann, B., and Liebermann, D.A. 1992. Genotoxic-stress-response genes and growth-arrest genes: gadd, MyD, and other genes induced by treatments eliciting growth arrest. Annals of the New York Academy of Sciences, 663: 139-53.

Fornace. A.D. Jr., Nebert, D.W., Hollander, M.C., Luethy, J.D., Papathanasiou, M., Fargnoli, J., and Holbrcok, N.J. 1989. Mammalian genes coordinately regulated by growth arrest signals and DNA- damaging agents. Molecular and Cellular Biology, 9: 4196-4203.

Gasch, A.P., Spellman, P.T., Kao, C.M., Carmel-Harel, O., Eisen, M.B., Storz, G., Botstein, D., and Brown, P.O. 2000. Genomic expression programs in the response of yeast cells to environmental changes. Molecular Biology of the Cell, 11: 42414257.

Gething, M.J., and Sambrook, J. 1992. Protein folding in the cell. Nature, 355: 33-45.

Gehring, W. J. and Wehner, R. 1995. Heat shock protein synthesis and thermotolerance in Cataglyphis, an ant from the Saharan desert. Proceedings of the National Academy of Sciences, 92: 2994-2998.

Gon, O. and Heemstra, P. C., ed. 1990. Fishes of the Southern Ocean, Grahamstown: J. L.B. Smith Institute of Ichthyology.

Gracey, A.Y., Troll, J.V., and Somero, G.N. 2001. Hypoxia-induced gene expression profiling in the euryoxic fish Gillichthys mirabilis. Proceedings of the National 
Academy of Sciences, 13;98(4): 1993-1998.

Harkin, D.P., Bean, J.M., Miklos, D., Song, Y.H., Truong, V.B., Englert, C., Christians, F.C., Ellisen, L.W., Maheswaran, S., Oliner, J.D., and Haber, D.A. 1999. Induction of GADD45- $\alpha$ and JNK/SAPK-dependent apoptosis following inducible expression of BRCA1. Cell, 97(5): 575-86.

Hartl, F.U. 1996. Molecular chaperones in cellular protein folding. Nature, 381: 571-80.

Hecker, M. and Volker, U. 2001. General stress response of Bacillus subtilis and other bacteria. Advances in Microbial Physiology. 44: 35-91.

Herr, I. and Debatin, K.M. 2001. Cellular stress response and apoptosis in cancer therapy. Blood, 98: 2603-2614.

Hochachka P.W., and Somero, G.N. 2002. Biochemical Adaptation: Mechanism and Process in Physiological Evolution. New York: Oxford Univ. Press.

Hofmann, G.E., Buckley, B.A., Airaksinen, S., Keen, J.E., and Somero, G.N. 2000. Heat-shock protein expression is absent in the Antarctic fish Trematomus bernacchii (family Nototheniidae). Journal of Experimental Biology, 203: 23312339.

Hofmann, G.E., Buckley, B.A., Place, S.P., and Zippay, M.L. 2002. Molecular Chaperones in Ectothermic Marine Animals: Biochemical Function and Gene Expression. Integrative and Comparative Biology, 42: 808-814.

Hofmann, G. E. and Somero, G. N. 1996. Interspecific variation in thermal denaturation of proteins in the congeneric mussels Mytilus trossulus and M. galloprovincialis: Evidence from the heat- shock response and protein ubiquitination. Marine Biology, 126, 65-75. 
Hunt, B. M., Hoefling, K. and Cheng, C.-H. C. 2003. Annual warming in seawater temperatures in McMurdo Sound in relationship to endogenous ice in notothenioid fish. Antarctic Science, 15: 333-338

Ikezoe, T., Gery, S., Yin, D., O’Kelly, J., Binderup, L., Lemp, N., Taguchi, H., and Koeffler, H. P. 2005. CCAAT/Enhancer-Binding Protein $\delta:$ A Molecular Target of 1,25-Dihydroxyvitamin D3 in Androgen-Responsive Prostate Cancer LNCaP Cells. Cancer Research, 65: 4762-4768.

Jin, S., Tong, T., Fan, W., Fan, F., Antinore, M. J., Zhu, X., Mazzacurati, L., Li, X., Petrik, K. L., Rajasekaran, B., Wu, M., and Zhan, Q. 2002. GADD45-induced cell cycle G2-M arrest associates with altered subcellular distribution of cyclin B1 and is independent of p38 kinase activity. Oncogene, 21(57): 8696-704.

Johnson, P. 2005. Molecular stop signs: regulation of cell cycle arrest by C/EBP transcription factors. Journal of Cell Science, 118: 2545-2555.

Kassahn, K.S., Caley, M.J., Ward, A.C., Connolly, A.R., Stone, G. and Crozier, R.H. 2007. Heterologous microarray experiments used to identify the early gene response to heat stress in a coral fish. Molecular Ecolology, 16: 1749-1763.

Kastan, M.I.B., Zhan, Q., El-Deiry, W.S., Carrier, F., Jacks, T., Walsh, W.V., Plunkett, B.S., Bogelstein, B., and Fornance, A.J. Jr. 1992. A mammalian cell cycle checkpoint pathway utilizing p53 and GADD45 is defective in ataxiatelangiectasia. Cell, 71: 587-597.

Kearsey, J.M., Coates P.J., Prescott, A.R., Warbrick, E., Hall P.A. 1995. Gadd45 is a nuclear cell cycle regulated protein which interacts with p21Cip1. Oncogene, 11(9): 1675-83. 
Kelman, Z., and Hurwitz, J. 1998. Protein-PCNA interactions: a DNA-scanning mechanism? Trends in Biochemical Sciences, 23: 236-238.

Kennett, J.P. 1977. Cenozoic evolution of Antarctic glaciation, the circum-Antarctic Ocean, and their impact on global paleoceanography. Journal of Geophysical Research, 82: 3843-3860.

Krebs, R.A. and Bettencourt, B.R. 1999. Evolution of thermotolerance and variation in the heat shock protein, Hsp70. American Zoologist, 39: 910-919.

Kültz, D. 2003. Evolution of the cellular stress proteome: from monophyletic origin to ubiquitous function. Journal of Experimental Biology, 206: 3119-3124.

Kültz, D. 2005. Molecular and evolutionary basis of the cellular stress response. Annual Review of Physiology, 67: 225-257.

Lele, Z., Engel, S. and Krone, P.H. 1997. hsp 47 and hsp70 gene expression is differentially regulated in a stress- and tissue-specific manner in zebrafish embryos. Developmental Genetics, 21: 123-133.

Liebermann, D.A. and Hoffman, B. 2002. Myeloid differentiation (MyD)/growth arrest DNA damage (GADD) genes in tumor suppression, immunity and inflammation. Leukemia, 16 (4): 527-41.

Lieschke, G. and Currie, P. 2007. Animal models of human disease: zebrafish swim into view. Nature, 8: 353-367.

Lindquist, S. 1986. The heat-shock response. Annual Review of Biochemistry, 55: 11511191. 
Liu, Yuangang., and Kulesz-Martin, M. 2001. p53 protein at the hub of cellular DNA damage response pathways through sequence-specific and non-sequence-specific DNA binding. Carcinogenesis, 22(6): 851-860.

Macario, A. J., Lange, M., Ahring, B. K. and de Macario, E. C. 1999. Stress genes and proteins in the archaea. Microbiology and Molecular Biology Reviews, 63: 923967.

Mak, S.K., and Kültz, D. 2004. Gadd45 proteins induce G2/M arrest and modulate apoptosis in kidney cells exposed to hyperosmotic stress. Journal of Biological Chemistry, 279: 39075-39084.

Marques, I. J., Leito, J.T.D., Spaink, H.P., Testerink, J., Jaspers, R.T., Witte, F., van den Berg, S., and Bagowski, C.P. 2008. Transcriptome analysis of the response to chronic constant hypoxia in zebrafish hearts. Journal of Comparative Physiological Biology, 178: 77-92.

Morimoto R.I., Tissieres A., and Georgopoulos C., eds. 1994. Heat Shock Proteins: Structure, Function and Regulation. Cold Spring Harbor, NY: Cold Spring Harbor Laboratory Press.

Nikinmaa, M., and Rees, B.B. 2005. Oxygen dependent gene expression in fish. American Journal of Physiology: Regulatory, Integrative and Comparative Physiology, 288: 1079-1090.

O’Rourke, J.P., Newbound, G.C., Hutt, J.A. and DeWille, J. 1999. CCAAT/enhancerbinding protein delta regulates mammary epithelial cell $\mathrm{G}_{0}$ growth arrest and apoptosis. Journal of Biological Chemistry, 23: 16582-16589.

Pearce, A. K. and Humphrey, T. C. 2001. Integrating stress-response and cell cycle 
checkpoint pathways. Trends Cell Biology. 11: 426-433.

Peretz, G., Bakhrat, A. and Abdu, U. 2007. Expression of the Drosophila melanogaster GADD45 homolog (CG11086) affects egg asymmetric development that is mediated by the c-Jun N-terminal kinase pathway. Genetics, 177(3): 1691-702.

Porter, D.A., Krop. I.E., Nasser, S., Sgroi, D., Kaelin, C.M., Marks, J.R., Riggins, G., and Polyak, K. 2001. A sage (serial analysis of gene expression) view of breast tumor progression. Cancer Research, 61: 5697-5702.

Porter, D.A., Lahit-Domenici, J., Keshaviah, A., Bae, Y.K., Argani, P., Marks, J., Richardson, A., Cooper, A., Strausberg, R., Riggeins, G.J., Schnitt, S., Gabrielson, E., Gelman, R. and Polyak, K. 2003. Molecular markers in ductal carcinoma in situ of the breast. Molecular Cancer Research, 1: 362-375.

Ramji, D.P. and Foka, P. 2002. CCAAT/enhancer-binding proteins: structure, function and regulation. Journal of Biochemistry, 365: 561-575.

Rees, B.B., Sudradjat, F.A. and Love, J.W. 2001. Acclimation to hypoxia increases survival time of zebrafish, Danio rerio, during lethal hypoxia. Journal of Experimental Zoology, 289: 266-272.

Richards, J. G. 2009. Metabolic and molecular responses of fish to hypoxia. In Hypoxia, Vol. 27 (ed. Richards JG, Farrell AP, Brauner CJ), pp. 443-485.

Ritossa, F. 1962. A new puffing pattern induced by temperature shock and DNP in Drosophila. Experiential Cellular and Molecular Life Sciences, 18: 571-573.

Roelofs, D., Morgan, J., and Stürzenbaum, S. 2010. The significance of genome-wide transcriptional regulation in the evolution of stress tolerance. Evolutionary Ecology, 24(3): 527-539. 
Roelofs D., Marie N.J., and Van Straalen, N.M. 2007. Differential gene expression profiles associated with heavy metal tolerance in the soil insect Orchesella cincta. Insect Biochemistry and Molecular Biology, 37: 287-295.

Rudolph, B., Gebendorfer, K.M., Buchner, J. and Winter, J. 2010. Evolution of Escherichia coli for Growth at High Temperatures. Journal of Biological Chemistry, 285: 19029-19034.

Ryan, H.E., Poloni, M., McNulty, W. Elson, D., Gassmann, M., Arbeit, J. M., Johnson, R. S. 2000. Hypoxia-inducible factor-1alpha is a positive factor in solid tumor growth. Cancer Research, 60: 4010-4015.

Sanders, B. M., Hope, C., Pascoe, V. M. and Martin, L. S. 1991. Characterization of stress protein response in two species of Colisella limpets with different temperature tolerances. Physiological Zoology, 64: 1471-1489.

Shang, E. H., and Wu, R. S. 2004. Aquatic hypoxia is a teratogen and affects fish embryonic development. Environmental Science \& Technology, 38(8): 4763-7476.

Sheikh, M.S., Hollander, M.C., and Fornance, A.J. Jr. 2000. Role of Gadd45 in apoptosis. Biochemical Pharmacology, 1;59(1): 43-5.

Shevenell, A.E., Kennett, J.P., and Lea, D.W. 2004. Middle Miocene Southern Ocean Cooling and Antarctic Cryosphere Expansion. Science, 305(5691): 1766-1770.

Sidell, B.D., and O'Brien, K.M. 2006. When bad things happen to good fish: the loss of hemoglobin and myoglobin expression in Antarctic icefishes. Journal of Experimental Biology, 209: 1791-1802.

Sinha, B., Chawla, A., and Goswami, P. 2009. Cross tolerance of two aviation stressesAcute heat stress and hypoxia. Indian Journal of Aerospace Medicine, 53(2): 10-16. 
Sivko, G.S., and DeWille, J.W. 2004. CCAAT/Enhancer binding protein delta (C/EBPdelta) regulation and expression in human mammary epithelial cells: I. "Loss of function" alterations in the c/EBPdelta growth inhibitory pathway in breast cancer cell lines. Journal of Cellular Biochemistry, 93: 830- 843.

Sluyser, M. ed. 2005. Apoptosis in Normal Development and Cancer. Taylor \& Francis Inc.

Somero, G.N. and DeVries, A.L. 1967. Temperature tolerance of some Antarctic fishes. Science, 156: 257-258.

Somero, G.N., and Hochachka, P.W. 1969. Isozymes and short-term temperature compensation in poikilotherms: activation of LDH isozymes by temperature decrease. Nature, 223: 194-195.

Takekawa, M., and Saito, H. 1998. A family of stress-inducible GADD45- $\alpha$-like proteins mediate activation of the stress-responsive MTK1/MEKK4 MAPKKK. Cell, 95: $521-530$.

Tang, B., Sivko, G.S., and DeWille, J. 2005. Promoter methylation reduces C/EBP delta gene expression in the SUM-52PE human breast cancer cell line and in primary breast tumors. Breast Cancer Research Treatments, 95: 161-170.

Thangaraju, M., Rudelius, M., Bierie, B., Raffeld, M., Sharan, S., Henninghausen, L., Huang, A., and Sterneck, E. 2005. C/EBPס is a crucial regulator of pro-apoptotic gene expression during mammary gland involution. Development, 132: 4675-4685. Tomanek, L. and Somero, G. N. 1999. Evolutionary and acclimation-induced variation in the heat-shock responses of congeneric marine snails (genus Tegula) from 
different thermal habitats: implications for limits of thermotolerance and biogeography. Journal of Experimental Biology, 202: 2925-2936.

Ton, C., Stamatiou, D., and Liew, C-C. 2003. Gene expression profile of zebrafish exposed to hypoxia during development. Physiological Genomics, 13: 97-106.

Vairapandi, M., Balliet, A.G., Hoffman, B., and Liebermann, D.A. 2002. GADD45 $\beta$ and GADD45 $\gamma$ are cdc2/CyclinB1 kinase inhibitors with a role in $\mathrm{S}$ and $\mathrm{G} 2 / \mathrm{M}$ cell cycle checkpoints induced by genotoxic stress. Journal of Cell Physiology, 192: 327-338.

van der Meer, D.L.M, van den Thillart, G.E.E.J.M, Witte, F., de Bakker, M.A.G., Besser, J., Richardson, M.K., Spaink, H.P., Leito, J.T.D., and Bagowski, C.P. 2005. Gene expression profiling of the long-term adaptive response to hypoxia in the gills of adult zebrafish. American Journal of Physiology: Regulatory, Integrative and Comparative Physiology, 289: 1512-1519

Van Straalen, N.M. and Roelofs, D. 2006. An Introduction to Ecological Genomics. Oxford University Press, Oxford.

Vaupel, P., and Harrison, L. 2004. Tumor hypoxia: causative factors, compensatory mechanisms, and cellular response. The Oncologist, 9(5): 4-9.

Vaupel, P., Kallinowski, F., Okunieff, P. 1989. Blood flow, oxygen and nutrient supply, and metabolic microenvironment of human tumors: a review. Cancer Research, 49: 6449-6465.

Vaupel, P., and Mayer, A. 2007. Hypoxia in cancer: significance and impact on clinical outcome. Cancer Metastasis Review, 26(2): 225-39.

Waters, E. 1995. The molecular evolution of the small heat-shock proteins in plants. 
Genetics, 141: 785-795.

Waters, E.R., Lee, G. J., and Vierling, E. 1996. Evolution, structure and function of the small heat shock proteins in plants. Journal of Experimental Botany, 47: 325-338.

Zhan, Q., Antinore, M. J., Wang, X.W., Carrier, F., Smith, M.L., Harris, C.C., and Fornace, A.J. Jr. 1999. Association with Cdc2 and inhibition of Cdc2/Cyclin B1 kinase activity by the p53-regulated protein Gadd45. Oncogene, 18: 2892-2900.

Zhang, W., Bae, I., Krishnaraju, K., Azam, N., Fan, W., Smith, K., Hoffman, B., and Liebermann, D.A. 1999. CR6: A third member in the MyD118 and Gadd45 gene family which functions in negative growth control. Oncogene, 18 (35): 4899-907.

Zhang, W., Hoffman, B. and Liebermann, D. A. 2001. Ectopic expression of MyD118/Gadd45/CR6 (Gadd45beta/alpha/gamma) sensitizes neoplastic cells to genotoxic stress-induced apoptosis. International Journal of Oncology, 18: 749757. 


\section{Appendix}

Table 1. Antibodies that were unsuccessful in detecting their target proteins in specific tissues from the target species of this thesis.

\begin{tabular}{ccc}
\hline Species & Tissue & Antibody \\
\hline Danio rerio & White muscle & C/EBP- $\delta$ \\
\hline Danio rerio & Brain & C/EBP- $\delta$ \\
\hline Danio rerio & White muscle & gadd45- $\alpha$ \\
\hline Danio rerio & White muscle & Actin \\
\hline Danio rerio & White muscle & Cyclin-D \\
\hline Danio rerio & White muscle & PCNA \\
\hline Danio rerio & White muscle & HIF-1 $\alpha$ \\
\hline Trematomus bernacchii & Liver & gadd45- $\alpha$ \\
\hline Trematomus bernacchii & Gill & gadd45- $\alpha$ \\
\hline Trematomus bernacchii & White muscle & gadd45- $\alpha$ \\
\hline Trematomus bernacchii & Liver & \\
\hline
\end{tabular}

